\title{
Assessment of Shoreline Transformation Rates and Landslide Monitoring on the Bank of Kuibyshev Reservoir (Russia) Using Multi-Source Data
}

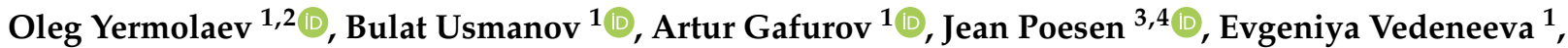 \\ Fedor Lisetskii ${ }^{5}$ (D) and Ionut Cristi Nicu $6,7, *$ (D)
}

1 Department of Landscape Ecology, Institute of Environmental Sciences, Kazan Federal University, 5 Tovarisheskaya Street, 420097 Kazan, Russia; oyermol@kpfu.ru (O.Y.); busmanof@kpfu.ru (B.U.); amgafurov@kpfu.ru (A.G.); vedeneeva-evgeniya@mail.ru (E.V.)

2 Institute of Earth Sciences, Belgorod State National Research University, 308015 Belgorod, Russia

3 Department of Earth and Environmental Sciences, KU Leuven, 3001 Leuven, Belgium; jean.poesen@kuleuven.be

4 Institute of Earth and Environmental Sciences, UMCS, 20-718 Lublin, Poland

5 Federal and Regional Center for Aerospace and Surface Monitoring of the Objects and Natural Resources, Belgorod State National Research University, 308015 Belgorod, Russia; liset@bsu.edu.ru

6 High North Department, Norwegian Institute for Cultural Heritage Research (NIKU), Fram Centre, N-9296 Tromsø, Norway

check for

updates

Citation: Yermolaev, O.; Usmanov, B.; Gafurov, A.; Poesen, J.; Vedeneeva, E.; Lisetskii, F.; Nicu, I.C. Assessment of Shoreline Transformation Rates and Landslide Monitoring on the Bank of Kuibyshev Reservoir (Russia) Using Multi-Source Data. Remote Sens. 2021, 13, 4214. https://doi.org/ $10.3390 /$ rs13214214

Academic Editors: Qingkai Meng, Federica Bardi, Pierluigi Confuorto, Giulia Dotta and Diego Di Martire

Received: 23 September 2021

Accepted: 19 October 2021

Published: 21 October 2021

Publisher's Note: MDPI stays neutral with regard to jurisdictional claims in published maps and institutional affiliations.

Copyright: (c) 2021 by the authors. Licensee MDPI, Basel, Switzerland. This article is an open access article distributed under the terms and conditions of the Creative Commons Attribution (CC BY) license (https:// creativecommons.org/licenses/by/ $4.0 /)$.
7 College of Humanities, Arts and Social Sciences, Flinders University, Adelaide, SA 5042, Australia

* Correspondence: ionut.cristi.nicu@niku.no; Tel.: +47-98063607

\begin{abstract}
This study focuses on the Kuibyshev reservoir (Volga River basin, Russia)—the largest in Eurasia and the third in the world by area $\left(6150 \mathrm{~km}^{2}\right)$. The objective of this paper is to quantitatively assess the dynamics of reservoir bank landslides and shoreline abrasion at active zones based on the integrated use of modern instrumental methods (i.e., terrestrial laser scanning-TLS, unmanned aerial vehicle-UAV, and a global navigation satellite system-GNSS) and GIS analysis of historical imagery. A methodology for the application of different methods of instrumental assessment of abrasion and landslide processes is developed. Different approaches are used to assess the intensity of landslide and abrasion processes: the specific volume and material loss index, the planar displacement of the bank scarp, and the planar-altitude analysis of displaced soil material based on the analysis of slope profiles. Historical shoreline position $(1958,1985$, and 1987) was obtained from archival aerial photo data, whereas data for 1975, 1993, 2010, 2011, and 2012 were obtained from high-resolution satellite image interpretation. Field surveys of the geomorphic processes from 2002, 2003, 2005, 2006, 2014 were carried out using Trimble M3 and Trimble VX total stations; in 2012-2014 and 2019 TLS and UAV surveys were made, respectively. The monitoring of landslide processes showed that the rate of volumetric changes at Site 1 remained rather stable during the measurement period with net material losses of $0.03-0.04 \mathrm{~m}^{-3} \mathrm{~m}^{-2} \mathrm{yr}^{-1}$. The most significant contribution to the average annual value of the material loss was snowmelt runoff. The landslide scarp retreat rate at Site 2 showed a steady decreasing trend, due to partial overgrowth of the landslide accumulation zone resulting in its relative stabilization. The average long-term landslide scarp retreat rate is-2.3 $\mathrm{m} \mathrm{yr}^{-1}$. In 2019 earthworks for landscaping at this site have reduced the landslide intensity by more than 2.5 times to- $-0.84 \mathrm{~m} \mathrm{yr}^{-1}$.
\end{abstract}

Keywords: bank erosion; landslide; aerial and satellite images; historical maps; TLS; UAV; Volga

\section{Introduction}

Creating reservoirs is known to develop and support several industries: i.e., electricity, agriculture, water transport, fisheries, recreation, and tourism. At the same time, their creation leads to a fundamental restructuring of natural systems: river water flow and 
regime, bedload, and suspended sediment yield are changed, a unique microclimate is created and landscapes are transformed [1-4]. The intensity of exogenous processes acting on the shore and banks increases by orders of magnitude due to the water surface area increase. This very complex relief-forming process (together with erosion and gravitational processes) is often called bank transformation when dealing with water reservoirs. Among all modified shores of water reservoirs in Russia, approximately $78 \%$ are destroyed by abrasion type, and the remaining $22 \%$-by abrasion-landslide, abrasion-karst, and other types of erosion processes $[5,6]$. When the banks are destroyed, a large sediment volume enters the reservoir. This leads to rapid siltation, reduction of water depths, and environmental degradation of the reservoir.

Exogenous geomorphic processes and their monitoring on the shores of water reservoirs have long been conducted [7]. A large number of different research methods have been used for this purpose [8]. Most often, the shoreline bank dynamics are evaluated, and there is limited quantitative data on the different exogenous processes, their intensity, and the particularities of soil transport on slopes. This is mainly due to poor field accessibility for making observations at the shoreline banks and for installing a reference point network (steep banks, high water level near the shore, bank collapse, crumbling, and landsliding). New opportunities for assessing the rate of shoreline modification by exogenous processes, particularly for shoreline areas that previously were difficult to access have emerged with the use of multi-source data (laser scanners, UAVs, remote sensing, etc.). Simultaneously, a large diversity of water reservoir types and natural-anthropogenic conditions shaping their banks has resulted in a specific spectrum of exogenic processes. This makes data generalization and spatial extrapolation difficult.

The objective of this study is to better understand the shoreline and bank dynamics of the Kuibyshev reservoir-one of the largest reservoirs in the world. Research focuses on shoreline abrasion and landslide processes as the most significant exogenous natural hazards of bank modification. Attention to these processes has increased because a significant number of settlements, religious buildings, cattle burial grounds, and infrastructure (oil and gas pipelines, roads, power lines, etc.) are located on the reservoir shores. The shoreline abrasion and landslide processes on the banks near settlements often lead to emergencies: i.e., destruction of buildings, infrastructures, communications, disturbance, and total loss of (agricultural) lands bordering the reservoir. Shore transformation processes are still going on at a high rate even though the engineering project predicted the attenuation of these processes in 20 years after the reservoir creation. In this connection, it is necessary to monitor these dangerous exogenous geomorphic processes. The objective of this study is therefore to assess quantitatively the rates of shoreline abrasion and landslide deformation rates using an integrated approach that involves different monitoring techniques. The study sites for shoreline process dynamics were selected by the Ministry of Natural Resources and Ecology of the Russian Federation and the Federal Agency for Water Resources. These government agencies identified areas of the Kuibyshev reservoir banks with the most significant exogenous natural hazards for human settlements and infrastructure.

\subsection{Research Methods for Landslide Processes}

At present, there is a large spectrum of methods for monitoring and estimation the intensity of exogenous processes [5,9-14]. These mainly consist of collecting instrumental topographic surveys and remote sensing data, allowing the study of slope processes over several decades. In order to assess the rates of geomorphic processes occurring on the reservoir shores, this study applied alongside traditional methods (topographic field surveys) a set of modern methods: i.e., terrestrial laser scanning (TLS), unmanned aerial vehicle UAV, remote sensing, and a global navigation satellite system (GNSS). These techniques allow a quick recording with high accuracy for determining the shore process rates and displaced material volumes by landslides [15]. After a critical evaluation of the 
various methods and a description of the study area, we report on the methods applied in this study.

\subsubsection{Traditional Geodetic Methods for Studying Landslide Processes}

One of the most widely used and well-known landslide processes monitoring method is the ground survey with total stations and GNSS receivers. This approach is useful for accurately measuring the position of individual points in the field. The use of traditional theodolite and total station measurements can achieve millimeter-scale errors when determining point coordinates [9]. Total stations have been used to create a field of points with the subsequent creation of a digital model of the landslide morphology [10] and to monitor the landslide movement [16]. Generally, a relative coordinate system is used for the survey which creates a problem when comparing such data with geo-referenced data sources. It is therefore necessary to recalculate the position of the field points to allow plotting these into the global coordinate system by the specific position of the reference points [13].

The use of permanent control points allows measuring the dynamics of the landslide process with millimeter-scale accuracy. Similar error rates are provided by permanent robotic geodetic control systems on sites with high landslide process dynamics or special hazards to human life or buildings and structures [17]. The advantage of this surveying method is its high accuracy. The disadvantage is that the surveys take a long time; therefore, a limited number of points located in accessible places are selected. The development of TLS, UAVs, allowing to take large amounts of data in a short time, precisely and in detail describing the surveyed surface, makes the classical topographic survey an outdated approach [18].

Limited control of processes operating within the landslides and the displaced ground masses are the most significant disadvantages of traditional approaches. None of these methods provides comprehensive information on quantitative characteristics and mechanisms of erosion processes on slopes. Thus, the most effective methods for studying inaccessible slopes with landslides are the repeated morphological surveys with accurate referencing of multi-temporal data.

\subsubsection{Ground-Based Laser Scanning}

High accuracy and density of point clouds obtained with ground-based scanning permits the obtaining of highly detailed models of local landslide areas [11]. Compared with traditional methods (aerial photography interpretation, ground photogrammetric survey, field studies), laser scanning has several advantages. These include the possibility of studying even small landslides (up to several $\mathrm{m}^{2}$ ) and landslide bodies of different ages [19] and investigating dangerous or inaccessible areas with direct topographic measurements. Very precise results make it possible to estimate the intensity of slope processes and estimate the age of landslide bodies [20,21], to build detailed three-dimensional models and evaluate the slope stability [22].

Laser survey technologies are often used to solve practical problems. For example, for monitoring of landslides that threaten the safe use of transport infrastructure. Various techniques have been used for such monitoring, in particular, the "Stop and Go" approach, which involves the installation of a scanner on a mobile platform [23] or the technique of spatial data referencing, based on the weighted transformation of parameters to obtain more accurate data [24].

One of the essential uses of ground-based laser scanning is to study the dynamics of slope processes. Morphometric and structural analysis of multi-temporal TLS data allows obtaining spatially distributed characteristics of velocity, direction, and volume of slope-displaced material $[25,26]$. The study of relief dynamics requires repeated measurements of the object under study and their comparison with previous data, which requires geodetically accurate referencing provided by modern ground-based laser scanning technologies $[27,28]$. To achieve high accuracy of multitemporal scans adjustments different approaches have been applied: least-squares [29], Iterative Closest Point (ICP) [30] 
differential global positioning system (DGPS) [31], relative coordinate system [32-34]. One centimeter is an acceptable error for studying landslide processes due to the large volume changes occurring on the affected slopes [35].

The need to survey from several positions to provide full coverage of the slope surface is one of the disadvantages of ground laser scanning when studying landslide processes on the nearshore slopes. In the case of the small beach width, this is difficult and often impossible. Given the inaccessibility of bank slopes, more convenient survey methods are used, such as mobile laser scanning from a ship, which allows studying extended areas from the water at small waves [32]. A combination of high-resolution remote sensing data and several ground-based methods (Ground-Based Interferometric Synthetic Aperture Radar, TLS, and InfraRed Thermography) is effective as part of long-term monitoring and emergency management [15].

Studies of landslides near water bodies are mainly carried out on the coasts of seas and oceans [36]. Few scientific studies have been devoted to the monitoring of hazardous processes on slopes bordering reservoirs [3] Several publications on the Three Gorges Reservoir in China, created in 2003, stand out [37-39]. Here, landslides have caused significant damage to infrastructures on the shore and have threatened the life of the local population. In contrast, in Russia, there are many studies devoted to studying geomorphic processes on the banks of large reservoirs, because of the large-scale construction of hydroelectric power plants in the middle of the last century [40-45].

\subsubsection{The Use of UAVs}

Even though many sensors are currently available on ground, airborne, and spacebased platforms, methods using unmanned aerial vehicles are rapidly developing among all modern methods for exogenous processes monitoring [46,47]. The possibility of obtaining three-dimensional (3D) information about the terrain with high accuracy and spatial resolution opens up new horizons for studying landslide processes [48,49]. Further development of technologies such as robotics, photogrammetry [50] and, in particular, Structure-from-Motion (SfM) and computer vision [51], as well as GNSS, has given a rise to a whole range of studies using UAVs for research in the field of dynamic geomorphology [52-57].

Particular attention should be given to methodological and technical works in which UAVs are compared with other, already proven methods. For example, when comparing models obtained by TLS and UAV with the results of total station surveys, in grass vegetation covers, the UAV gives a model even more accurate than the TLS [58,59]. If the survey methodology is followed, UAVs' use allows one to survey and create a DEM with similar accuracy as the TLS on any landscape [60-63].

It is essential to consider GCP [64-68] and GNSS), the presence of which ensures the achievement of high modeling accuracy. As noted in Turner et al. [69], the non-use of ground control points resulted in a 6-10-fold increase in model accuracy relative to studies in which ground control points were used. The newest GNSS-receivers allow achieving a positioning error not exceeding $3-5 \mathrm{~mm}$ in height, which is sufficient even for microrelief reconstruction $[70,71]$.

\section{Study Area}

The Kuibyshev reservoir, built on the Volga River, is the largest in Eurasia and the third-largest in the world, after Volta (Ghana) and Smallwood (Canada) reservoirs. It is located in the central part of the Middle Volga basin at the intersection of the forest and forest-steppe landscape zones of the Volga uplands and the Low Volga [72] (Figure 1). The geographic coordinates of the reservoir's borders are $56^{\circ} 10^{\prime}-53^{\circ} 30^{\prime} \mathrm{N}, 47^{\circ} 30^{\prime}-49^{\circ} 30^{\prime} \mathrm{E}$. There are three orographic regions within its basin: Volga Upland, Vyatka Predkamye, Low Volga. The research was conducted within the Volga Upland on the right side of the reservoir; its banks are steep and cliffy. Absolute heights are $175-215 \mathrm{~m}$ in the north and $250-270 \mathrm{~m}$ in the south. The maximum altitudes are confined to the Zhigulevskiy 
Mountains (349 m). The climate is characterized as temperate continental, with relatively warm and humid summers, cool and moderately snowy winters. The annual precipitation depth is $500-540 \mathrm{~mm}$, in the warm season reaching $340-360 \mathrm{~mm}$. The snow cover height is $30-37 \mathrm{~cm}$, with a water equivalent of $90-95 \mathrm{~mm}$.

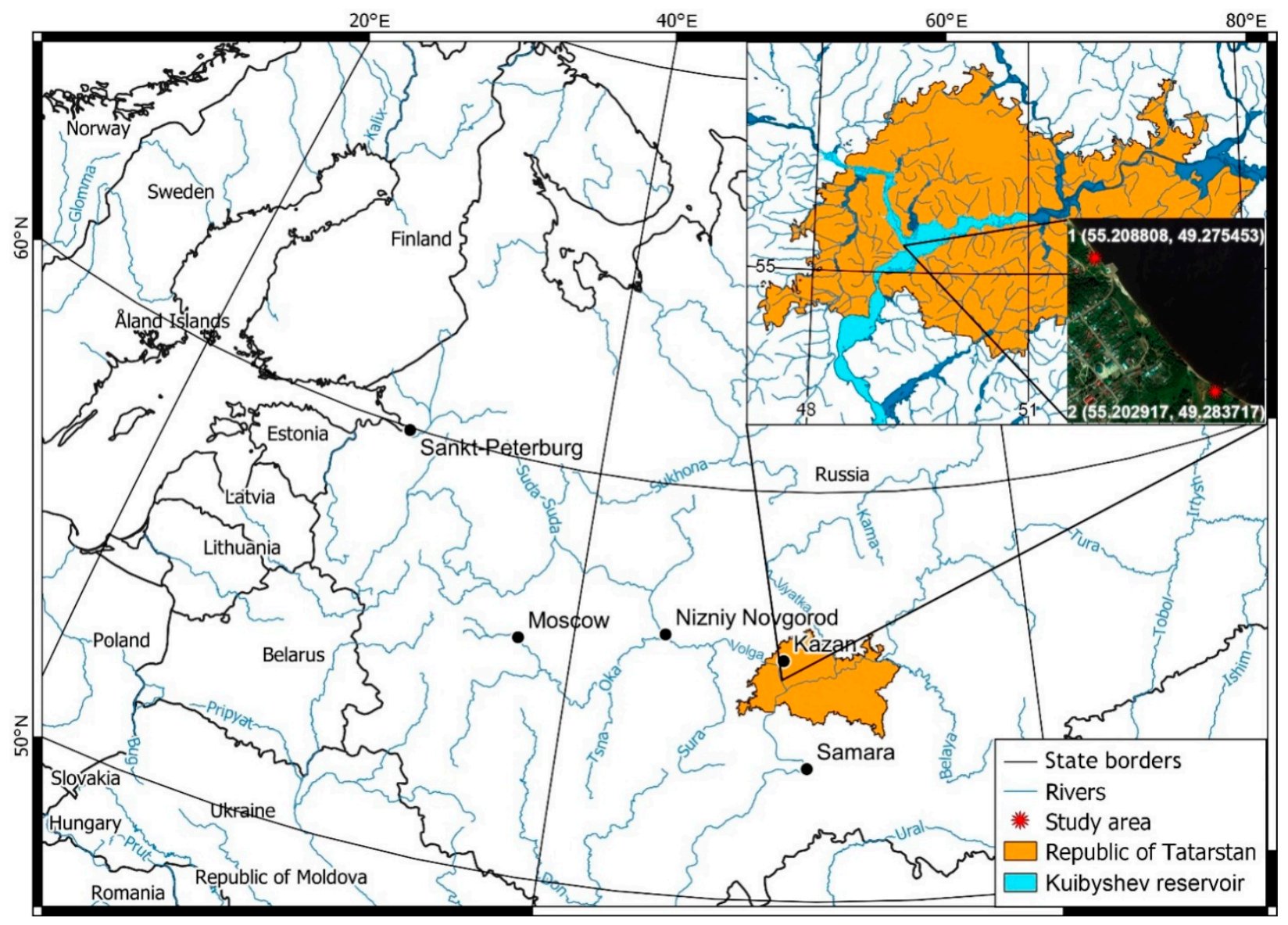

Figure 1. Location of the Kuibyshev reservoir on the Volga River and the two study sites in the East of the Russian Plain.

The reservoir was formed on 31 October 1955, following the Volga River damming by Kuibyshev hydroelectric complex. The reservoir reached its full reservoir level (FRL) of $53 \mathrm{~m}$ a.s.l. during the 1957 high waters. Its total capacity is $57.3 \mathrm{~km}^{3}$, its water surface area equals $6150 \mathrm{~km}^{2}$ and its total length along the Volga River is $510 \mathrm{~km}$ and $280 \mathrm{~km}$ along the Kama River. Its width varies between 2 and $27 \mathrm{~km}$ with a maximum of $38 \mathrm{~km}$ at Kamskoe Ustye. The average water depth is $9.4 \mathrm{~m}$, maximum is $41 \mathrm{~m}$. The length of the coastline is $2604 \mathrm{~km}$, minimum navigation level is $49.00 \mathrm{~m}$. The reservoir is a seasonal flow regulation storage: the average annual conditional coefficient of water exchange is 4.3.

There are 79 rivers more than $10 \mathrm{~km}$ long and 260 rivers less than $10 \mathrm{~km}$ long flowing into the reservoir. The Volga, Kama, and Vyatka rivers, which directly form the reservoir's water mass, belong to the rivers with predominant snowmelt feeding. Surface and groundwater produce $99 \%$ and precipitation $1 \%$ of the water input into the reservoir. The water balance components determine the annual water level fluctuation in the reservoir. The inflow and outflow discharges are asynchronous, and their ratio determines the reservoir filling and drawdown. The reservoir fills up to the maximum level during spring floods, while in autumn and winter the level is at its lowest position. The annual amplitude of level fluctuations is about $6 \mathrm{~m}$. The average runoff velocity in the reservoir is $2-10 \mathrm{~cm} / \mathrm{s}$, depending on the value of transit flow and the live cross-sectional area. The morphological structure of the reservoir is a system with lake-like expansions. This reservoir serves several economic sectors: i.e., energy, water transport, agriculture and fisheries, industrial and municipal water supply. 
Two sites on the right bank of the Kuibyshev reservoir near Kamskoe Ustye village (Republic of Tatarstan) were selected to evaluate the intensity of shoreline abrasion and landsliding. Right-bank slopes of the Volga River have scars of ancient landslides. A significant rise in the water level due to the reservoir creation triggered the reactivation of landslide movements. The sites were selected based on their representativeness in terms of geological-geomorphological and landscape conditions for the study area. In addition, the economic aspect was considered since there is a threat of partial destruction of the buildings and infrastructure facilities according to the state authorities of the Russian Federation.

At site 1 not only landsliding but also abrasion processes at the shoreline have developed. The site is located on the right bank $30 \mathrm{~m}$ upstream of the Volga River pier (Figure 2). The landslide and abrasion process acting on the bank are observed here. In the upper part of the slope, composed of heavy and middle deluvial-solifluction loams, collapse and sliding of earth blocks of different volumes towards the shoreline occur. At the foot of the abrasion ledge in some places, there are outcrops of the Kazanian age deposits, i.e., clayey-melty gray pack of rocks of the upper Permian system.

The earth slide type landslide [73] has a frontal shape, its length is $32 \mathrm{~m}$, and its width is $55 \mathrm{~m}$ (total area is $1760 \mathrm{~m}^{2}$ ). An abrasion scarp has formed in the lower part of the slope with traces of landslides and washouts. In a slope profile, the landslide body itself is well identified in the upper part with a head scarp and in the lower part a terrace-shape section. The beach is $2.5-5.0 \mathrm{~m}$ wide and is composed of sand-and-shingle material. The abrasion section at the lower part of the slope erodes and collapses; soil blocks slide through cracks to the shoreline where they are eroded by water. Wave breaking caves are practically absent. Other exogenous processes are acting on the slope in addition to the dominant landslide process. There are rills and ephemeral gullies in the upper part of the slope and gravitational processes (collapse and crumbling) in the middle and lower part. However, they are of subordinate importance in terms of active slope processes.

At site 2, a large landslide of earth slide type [73] has formed as a result of mass movement processes. Here, the landslide-abrasion type of coastal escarpment is observed. Due to changes in groundwater outflow caused by water level rise, a sliding landslide develops (Figure 3), forming a large landslide cirque. The upper part of the landslide process led to the destruction of the old cemetery. Landslide length is $173 \mathrm{~m}$, and its width is $110 \mathrm{~m}$ (total area is $13,900 \mathrm{~m}^{2}$ ). The height of the landslide edge is $14.7 \mathrm{~m}$; the steepness is 90 degrees. The body of the landslide is hilly and canopy-shaped. The upper landslide scarp is close to the buildings.

The lower northern part of the landslide body is affected by very active slope subsidence of the earth block type. The slope is composed of deluvial-solifluction loams with the vertical type of clastic-block structure; blocks with shrub and woody vegetation are collapsing along the cracks.

The height of the blocks is 5-6 m, width up to 7-8 m. The soil surface of the old cemetery is deformed due to cracking and subsidence. The landslide bodies are located further down the slope, moving towards the Volga at low speed; their hilly surfaces are overgrown with willow, American maple, saltbush, common nettle, and coltsfoot. Behind the edge of this landslide body is the landslide cirque. Its southwestern cliff destroys the old cemetery. Numerous humans remains emerge from a depth of 1.5-2 $\mathrm{m}$ in the landslide escarpment. In the lower part of the slope, an abrasion scarp with traces of breakwater caves can be observed.

In 2018 to the south of the study Site 2, a shore reconstruction was carried out to organize a recreational area near the camping base (Figure 4). As a result of excavation works and re-organization of access roads to the camping base pier, the south-eastern part of the studied landslide cirque and landslide body was leveled and sodded (Figure 4B). As a result, this fragment of the landslide ledge was excluded from further analysis. However, the works carried out to improve the sloping area did not reduce the intensity of geomorphic processes, and the works on slope stabilization had to continue. 

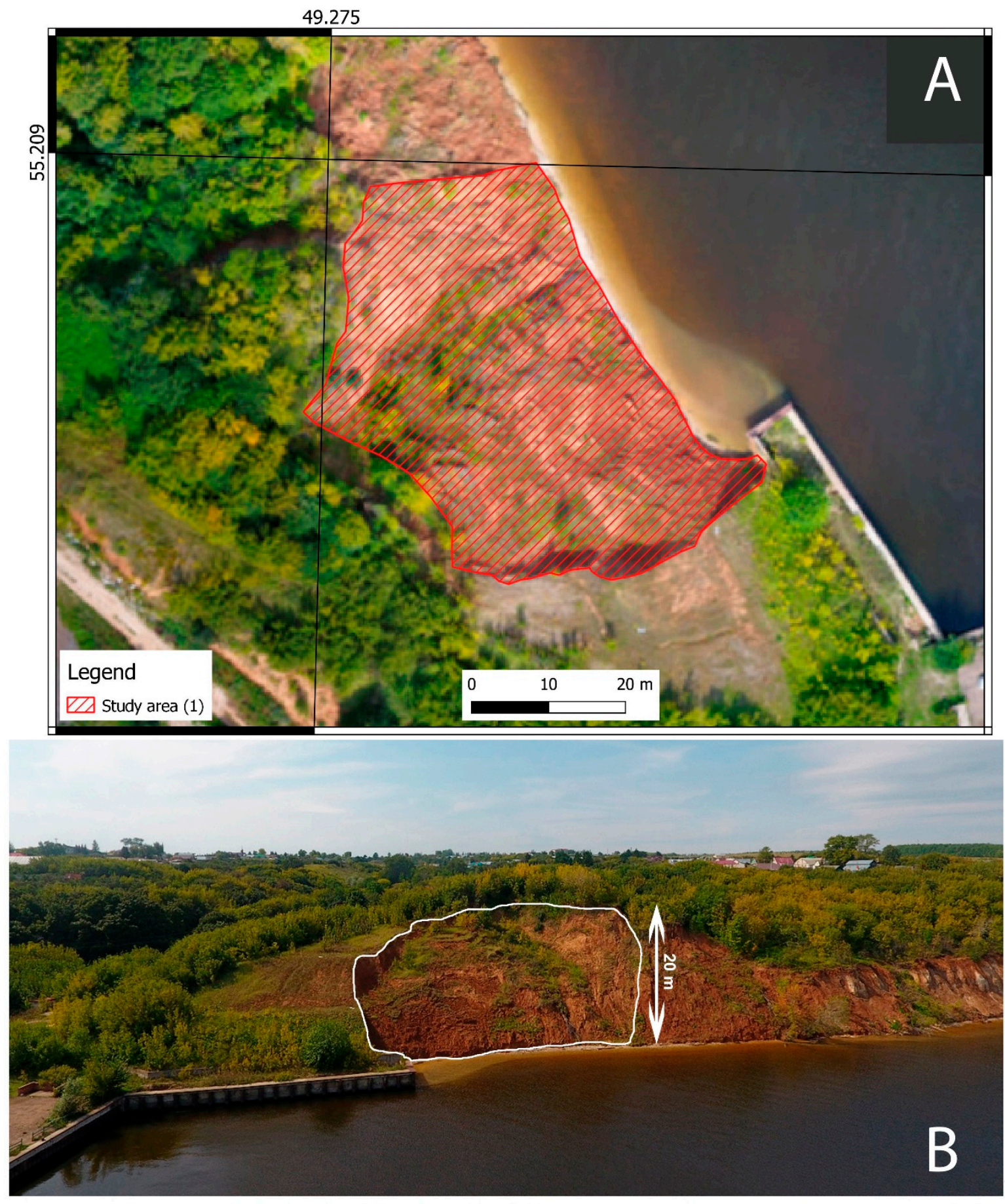

Figure 2. Aerial (2019) (A) and oblique views (B) of the shoreline and the landslide body at Site 1. 


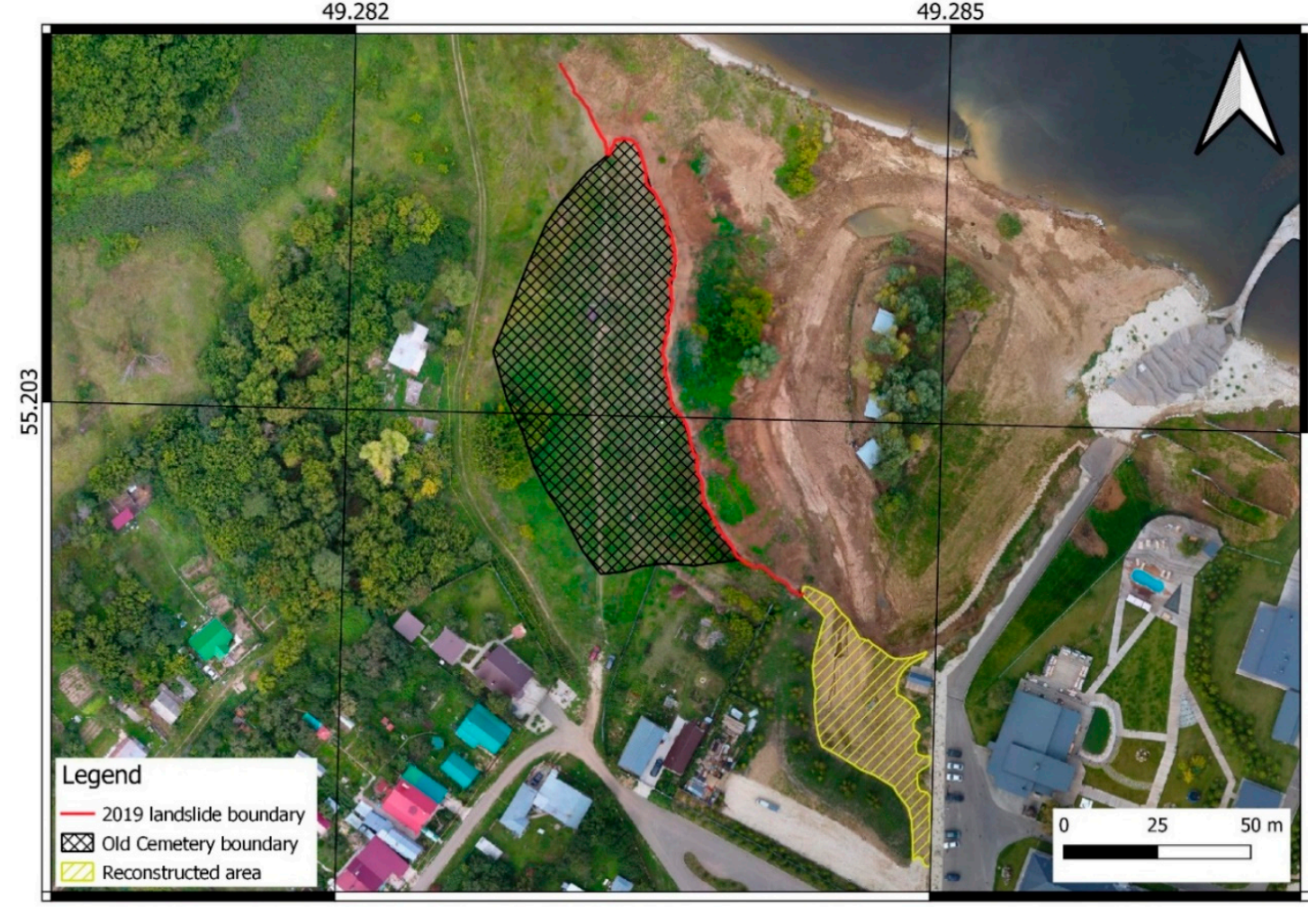

Figure 3. Aerial view (2019) of Site 2 with landslide polygon.
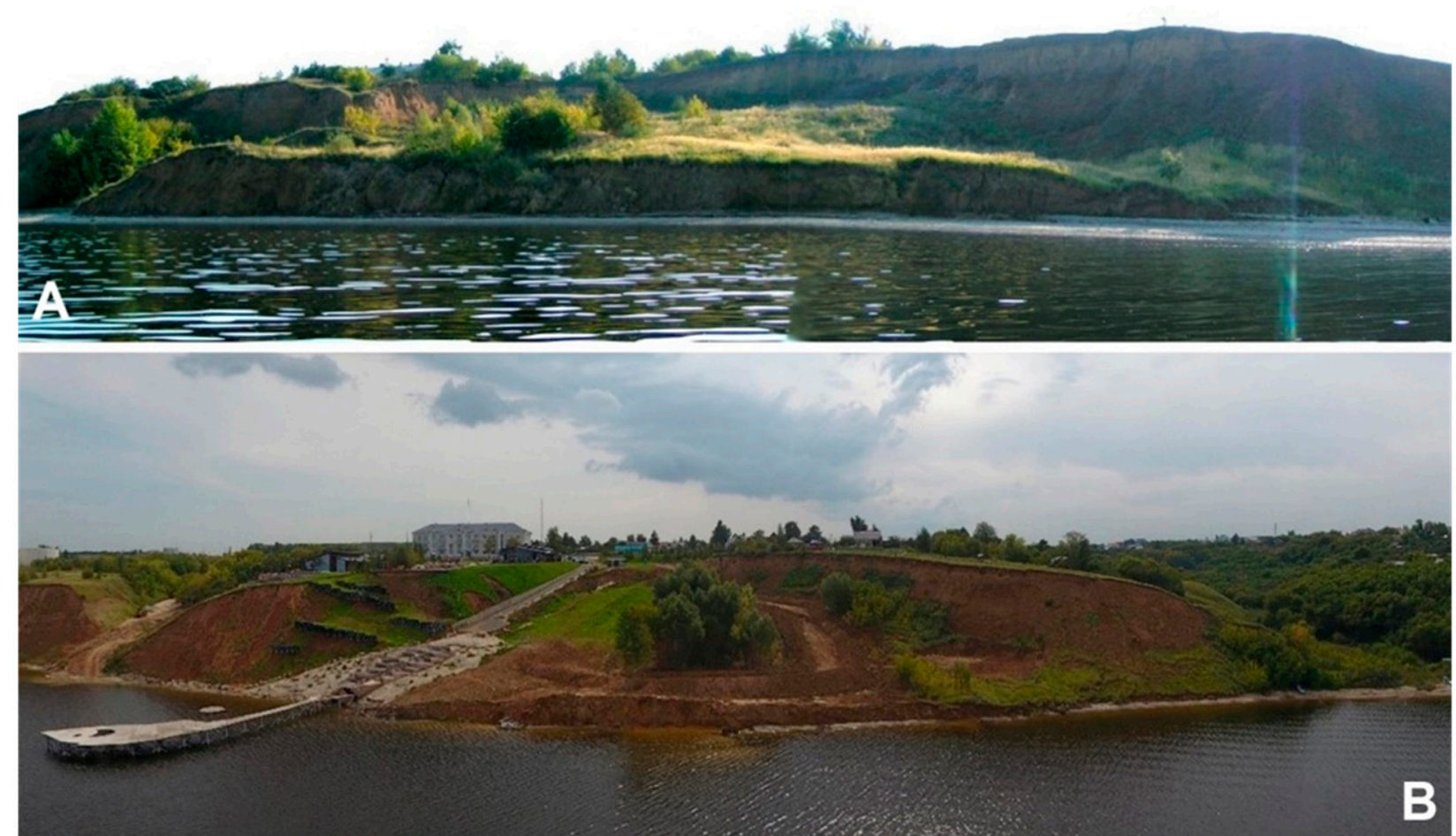

Figure 4. Cont. 

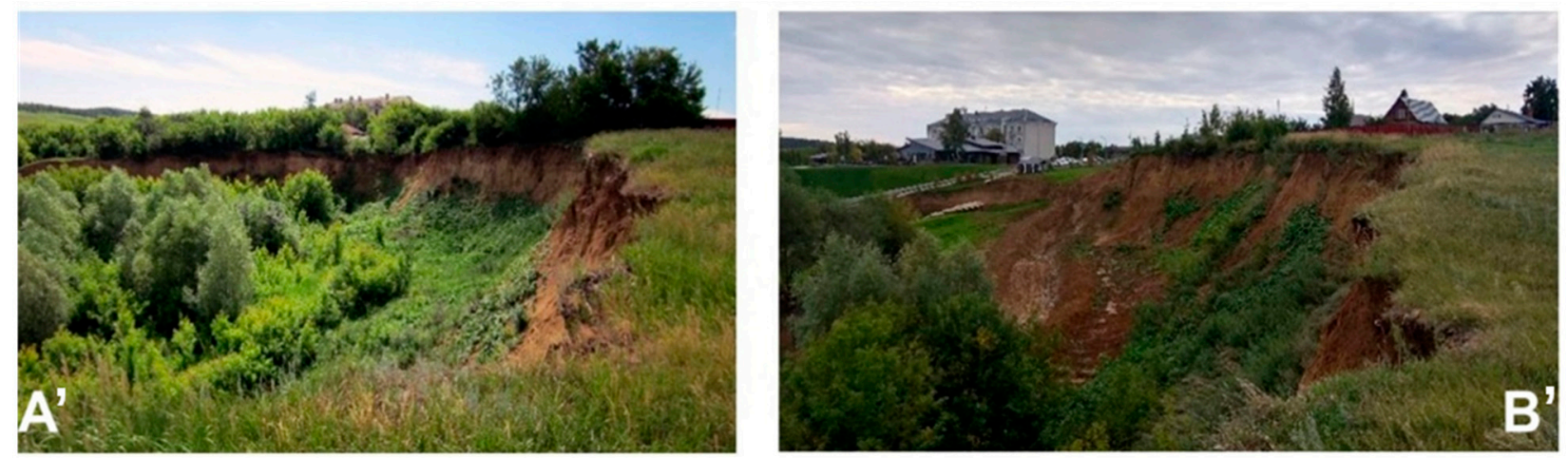

Figure 4. Views on the landslide at site 2 in 2003 ((A)—front view, (A') -lateral view) and in 2019 ((B) —front view, $\left(\mathbf{B}^{\prime}\right)$-lateral view).

\section{Materials and Methods}

Various sources of information and observation methods were combined to estimate the intensity of abrasion and landslide processes at the reservoir shores. Shoreline positioning for the past periods (1958, 1985, 1987, and 1993) was obtained from archived historical aerial images (Kazan University Library); data for 1975, 2010, were obtained from satellite imagery interpretation. Field measurements at the study sites were conducted in 2002, 2003, 2005, and 2006 using Trimble M3 total station (2014). Since traditional methods mainly provide information about the planar displacement of the landslide scarp edge, the laser scanning method was additionally used in 2012-2014 to study the volume changes in hard-to-reach and hazardous areas. A Trimble GX TLS used as scanning equipment (Figure 5, Table 1). From 2019 onwards, field surveys include a DJI Phantom 4 UAV survey.
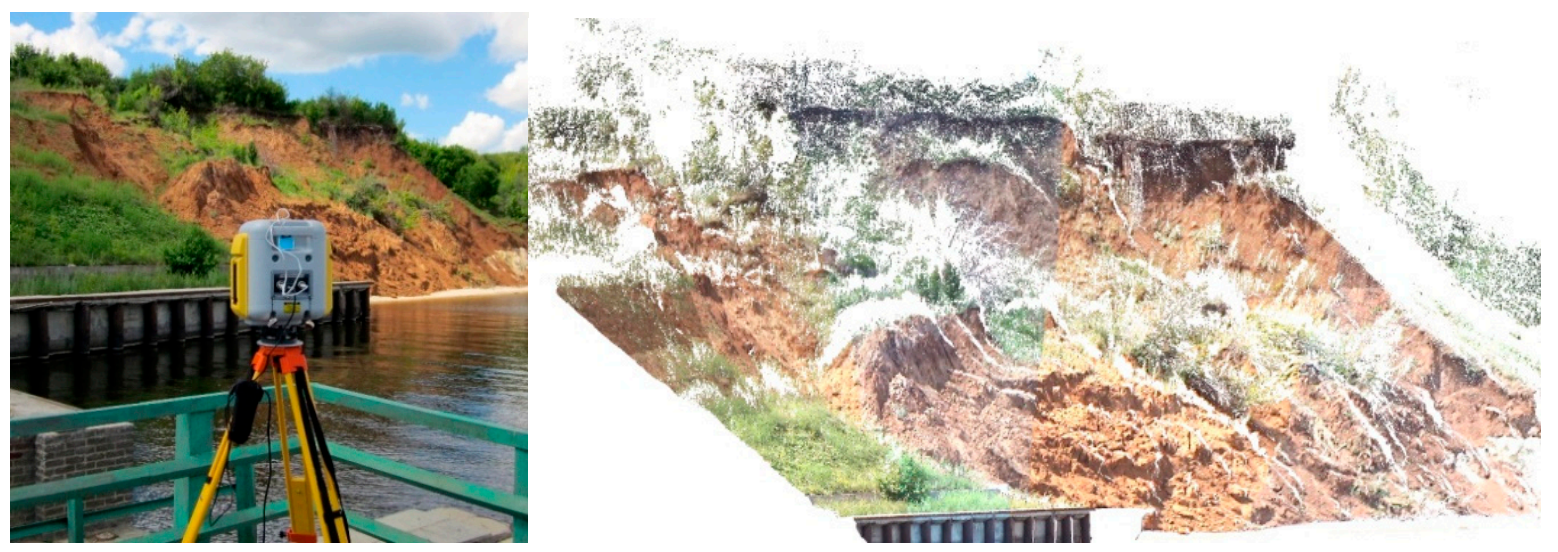

Figure 5. Used scanning equipment-Trimble GX and point clouds for Site 1 (2014).

Table 1. Number (\#) of laser scanning points at Site 1.

\begin{tabular}{cc}
\hline Scan Date & Site 1 (\#) \\
\hline July 2012 & $1,847,951$ \\
November 2012 & $2,271,130$ \\
July 2013 & 850,394 \\
November 2013 & $1,509,131$ \\
June 2014 & $1,550,689$ \\
\hline
\end{tabular}

Since the slope processes at the studied sites develop differently-a block landslide at Site 1 and a landslide cirque at Site 2, the methodological approaches for their study were also different. 


\subsection{Site 1}

At Site 1, an analysis of the abrasion-slope DEM obtained from ground-based laser scanning in 2012-2014 and UAV imagery in 2019 was chosen as the main method of shoreline deformation (Table 2).

Table 2. Dates and data acquisition techniques for Site 1.

\begin{tabular}{cc}
\hline Year-Month & Type of Measurement \\
\hline 2012-July, November & Laser Scan \\
2013-July, November & Laser Scan \\
2014-June & Laser scanning \\
2019-August & UAV \\
\hline
\end{tabular}

The results of scanning were processed in the Trimble Realworks software. The obtained point clouds were transformed to one coordinate system; next, the scans were cleaned from artifacts. The obtained point clouds were exported to the Golden Software Surfer software, whereby triangulation with linear interpolation of the DEM with a spatial resolution of $0.1 \mathrm{~m}$ was created. The calculation of volume change was performed using the Volume tool. In addition, qualitative analysis-creating maps of surface changes and analysis of landslide slope profile changes-was performed here. According to laser scanning results, a specific indicator such as the volume of eroded soil per unit area $\left(\mathrm{V}_{-} \mathrm{S}^{-1}\right.$, $0.03-0.04 \mathrm{~m}^{3} \mathrm{~m}^{-2}$ ) was used to estimate the intensity of landslide processes. Calculation of soil volumes between the scanned surfaces was carried out in automatic mode.

Photogrammetric processing of UAV survey results was performed in Agisoft Photoscan software. A combined approach was used to align the point clouds obtained by TLS and UAV surveys. Since the main survey using terrestrial laser scanning was carried out in the relative coordinate system and the UAV data in the global coordinate system, it was decided to recalculate the latter in the relative coordinate system. At the first stage, common stable areas were singled out on the point clouds obtained from different sources: i.e., elements of the pier, corners of buildings, and bank protection structures. Based on the obtained matches, the point clouds were re-aligned using the ICP method to minimize the georeferencing error (Table 3).

Table 3. Point clouds georeferencing errors for Site 1.

\begin{tabular}{ccccccc}
\hline \multirow{2}{*}{ Point № } & \multicolumn{3}{c}{ Manual Point Selection } & \multicolumn{3}{c}{ Iterative Closest Point Method (ICP) } \\
\cline { 2 - 6 } & $\mathbf{X}(\mathbf{m})$ & $\mathbf{Y}(\mathbf{m})$ & $\mathbf{Z}(\mathbf{m})$ & $\mathbf{X ~ ( m )}$ & $\mathbf{Y}(\mathbf{m})$ & $\mathbf{Z}(\mathbf{m})$ \\
\hline 1 & 0.09 & -0.18 & 0.63 & -0.05 & 0.11 & -0.20 \\
2 & -0.45 & 0.09 & 0.18 & 0.10 & 0.00 & 0.01 \\
3 & 0.09 & 0.27 & -0.36 & 0.00 & 0.16 & 0.12 \\
4 & 0.27 & -0.36 & 0.45 & -0.04 & 0.10 & -0.19 \\
5 & 0.36 & 0.45 & -0.54 & -0.11 & -0.28 & -0.16 \\
6 & 0.54 & 0.27 & 0.09 & 0.06 & -0.13 & 0.07 \\
7 & -0.18 & 0.09 & 0.09 & -0.03 & -0.06 & 0.03 \\
Total & $\mathbf{0 . 2 8}$ & $\mathbf{0 . 2 4}$ & $\mathbf{0 . 3 3}$ & $\mathbf{0 . 0 6}$ & $\mathbf{0 . 1 2}$ & $\mathbf{0 . 1 1}$ \\
\hline
\end{tabular}

The obtained errors are considered to be permissible in landslide process studies $[74,75]$.

To calculate quantitative characteristics and assess the intensity of the processes at Site 1, a series of maps of surface changes were constructed for the abrasion scarp and the upper part of the landslide slope. Changes on the slope were also studied by cross-section profiles along the slope surface.

\subsection{Site 2}

Analysis of landslide scarp retreat was chosen as the primary method for studying bank transformation at Site 2. A wide range of data was used to perform this task (Table 4). 
Table 4. Dates and data acquisition techniques and sources for Site 2.

\begin{tabular}{cc}
\hline Year & Source Data \\
\hline 1958 & Aerial image \\
1975 & “Corona" satellite image \\
1985 & Aerial image \\
1987 & Aerial image \\
1993 & Aerial image \\
2002 & Total Station Survey \\
2003 & Total Station Survey \\
2005 & Total Station Survey \\
2006 & Total Station Survey \\
2010 & Roscosmos satellite image \\
2019 & UAV data \\
\hline
\end{tabular}

Archived historical aerial and satellite images were used to study the changes in the shoreline position, and modern satellite images were used as a base for their spatial reference. Since 2002, a topographic survey was carried out in a relative coordinate system. A network of reference points was created, to provide a multi-term survey. The reference points' coordinates were determined using a Trimble M3 total station. The use of geodetic class marks provides high accuracy of the inter-seasonal and annual survey results referencing and subsequent aligning of the multi-temporal scans. A GNSS receiver using real-time kinematic corrections was used to transform the obtained results into the global coordinate system in 2012.

The Digital Shoreline Analysis System (DSAS), as an extension module of the ArcGIS software, was used to quantify shoreline displacement. The main application of DSAS is the use of polyline layers as a representation of a particular shoreline object at a particular point in time. Several statistical measures of shoreline change are compiled by comparing shoreline positions: net shoreline movement (NSM), shoreline change envelopes (SCE), endpoint rate (EPR), linear regression rate (LRR), and weighted linear regression rate (WLR) [76]. This module is effective for simplifying the analysis of shoreline position changes [77,78]. Shoreline's geodatabase was created in ArcGIS. The 1958 shoreline (immediately after filling the reservoir) was taken as a baseline. Following parameters were selected: distance between the transects is $15 \mathrm{~m}$, search radius is $300 \mathrm{~m}$. Based on the obtained transects, shoreline indicators such as linear retreat rate $\left(\mathrm{m} \mathrm{yr}^{-1}\right)$, shoreline displacement $(\mathrm{m})$ were automatically calculated.

\section{Results}

\subsection{Observations at Site 1}

Assessment of landslide and shoreline abrasion intensity at Site 1 is based on the volume of material displaced per unit area. According to the laser scanning results, changes were evaluated in the upper part of the slope, where a block type landslide was developing, and in the lower part, where an abrasion scarp was formed because of wave wash (Figure 6). The evolution of the situation at study site 1 was analyzed by comparing the results of laser scanning (Table 5) and those obtained during the 2019 UAV survey (Table 6).

The information on mobilized material volumes was obtained from the analysis of different maps from the study slope using the laser scanning results presented in Table 6. Ground displacements in the abrasion scarp area vary independently of the seasons, which is explained by the water level fluctuations of the reservoir. First, there is an accumulation of soil in the lower part of the slope due to landslide processes. In the case of high-water levels, the soil is eroded by wave abrasion. During water drawdown, the foreshore width does not allow the waves to erode the shore, and material accumulates again at the foot of the slope. This explains why denudation near the abrasion scarp prevails in 2012-2013, and accumulation processes prevailed in 2013-2014. 

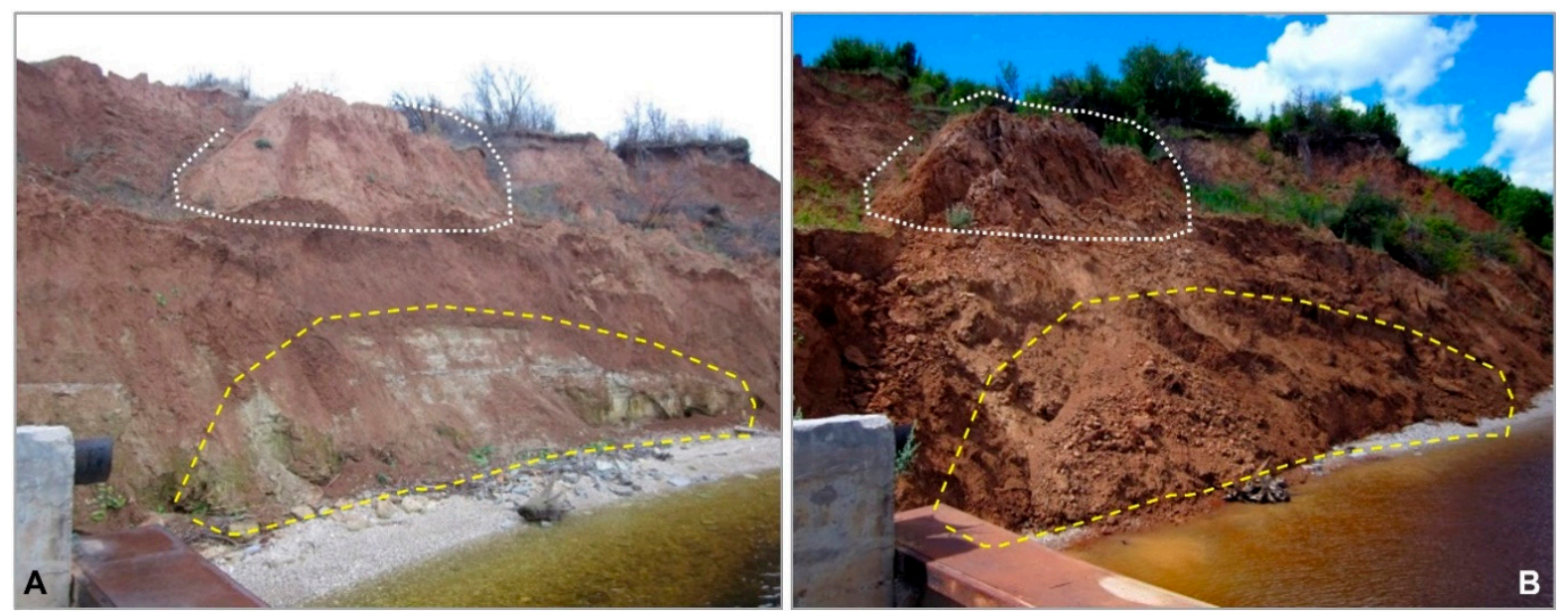

Figure 6. Site 1. Part of the study area in November 2013 (A) and June 2014 (B). The white line shows a block landslide, and the yellow line shows an abrasion scarp.

Table 5. Quantitative indices describing the intensity of geomorphic processes at Site 1 according to scanning results.

\begin{tabular}{cccc}
\hline \multirow{2}{*}{ Observation Period } & \multicolumn{2}{c}{ Abrasion Scarp } & \multicolumn{2}{c}{$\begin{array}{c}\text { Upper Part of the Slope } \\
\mathbf{V}_{-} \mathbf{S}^{-\mathbf{1}}, \mathbf{m}^{\mathbf{3}} \mathbf{m}^{-\mathbf{2}}\end{array}$} \\
\cline { 2 - 3 } & $\mathbf{V}_{-} \mathbf{S}^{-\mathbf{1}}{ }^{*}, \mathbf{m}^{\mathbf{3}} \mathbf{m}^{-\mathbf{2}}$ & $\mathbf{V}_{+} \mathbf{S}^{-\mathbf{1}}{ }^{*}, \mathbf{m}^{\mathbf{3}} \mathbf{m}^{-\mathbf{2}}$ & 0.06 \\
$06 / 2012-11 / 2012$ & 0.08 & 0.25 & 0.2 \\
$11 / 2012-06 / 2013$ & 0.67 & 0.06 & 0.25 \\
$\mathbf{0 6 / 2 0 1 2 - 0 7 / 2 0 1 3 * *}$ & $\mathbf{0 . 5 4}$ & 0.05 & 0.08 \\
$07 / 2013-11 / 2013$ & 0.02 & 0.02 & 0.08 \\
$11 / 2013-06 / 2014$ & 0.03 & $\mathbf{0 . 6 1}$ & $\mathbf{0 . 1 7}$ \\
$\mathbf{0 7 / 2 0 1 3 - 0 6 / 2 0 1 4}$ & $\mathbf{0 . 0 7}$ & \\
\hline
\end{tabular}

${ }^{*} \mathrm{~V}_{-} / \mathrm{S}$ represents the eroded soil volume per unit area; $\mathrm{V}+/ \mathrm{S}$ refers to the deposited soil volume per unit area. ${ }^{* *}$ The annual average values of eroded and accumulated volumes are in bold.

Table 6. Quantitative indicators characterizing the intensity of geomorphic processes at site 1 based on UAV survey results.

\begin{tabular}{|c|c|c|c|}
\hline Observation Period & $\mathrm{V}_{+} \mathrm{S}^{-1 *}, \mathrm{~m}^{3} \mathrm{~m}^{-2}$ & $\mathrm{~V}_{-} \mathrm{S}^{-1}{ }^{*}, \mathrm{~m}^{3} \mathrm{~m}^{-2}$ & $\Delta \mathrm{V} \mathrm{S}^{-1} \mathrm{~m}^{3} \mathrm{~m}^{-2}$ \\
\hline $06 / 2012-11 / 2012$ & 0.008 & 0.017 & -0.009 \\
\hline $11 / 2012-7 / 2013$ & 0.014 & 0.036 & -0.023 \\
\hline $06 / 2012-07 / 2013 * *$ & 0.012 & 0.044 & -0.033 \\
\hline $7 / 2013-11 / 2013$ & 0.003 & 0.022 & -0.019 \\
\hline $11 / 2013-6 / 2014$ & 0.014 & 0.026 & -0.012 \\
\hline $07 / 2013-06 / 2014$ & 0.009 & 0.040 & -0.031 \\
\hline 6/2014-8/2019 & 0.000 & 0.038 & -0.038 \\
\hline
\end{tabular}

${ }^{*} \mathrm{~V}_{-} / \mathrm{S}$ represents the eroded soil volume per unit area; $\mathrm{V}+/ \mathrm{S}$ refers to the deposited soil volume per unit area. $\Delta \mathrm{V} / \mathrm{S}$ is the net soil loss;

** The annual average values of eroded and accumulated volumes are in bold.

In general, for study site 1 denudation processes are dominant during the observation period (Table 6). The volume of landslide changes per unit area showed that intra-season and inter-annual dynamics of the process are irregular. The high intensity of the denudation process in the autumn-winter period of 2013 is noted because of a smooth increase of solar radiation and, therefore, low evaporation passing into snowmelt runoff. In addition, since there is no significant precipitation between December and March (Figure 7A), only AprilNovember data were used to analyze the role of precipitation. The comparable rates of the denudation process in the summer-autumn period of 2013 and autumn-winter period of 2014 are explained by a significant erosive $\left(>10 \mathrm{~mm} \mathrm{day}^{-1}\right)$ rainfall and, in contrast, by a less erosive winter precipitation (Figure 7B). However, despite the fundamentally different patterns of intra-annual variability of denudation processes, the inter-annual net material loss at site 1 remains, rather constant (ca. $-0.03 \mathrm{~m}^{3} \mathrm{~m}^{-2}$ ). 


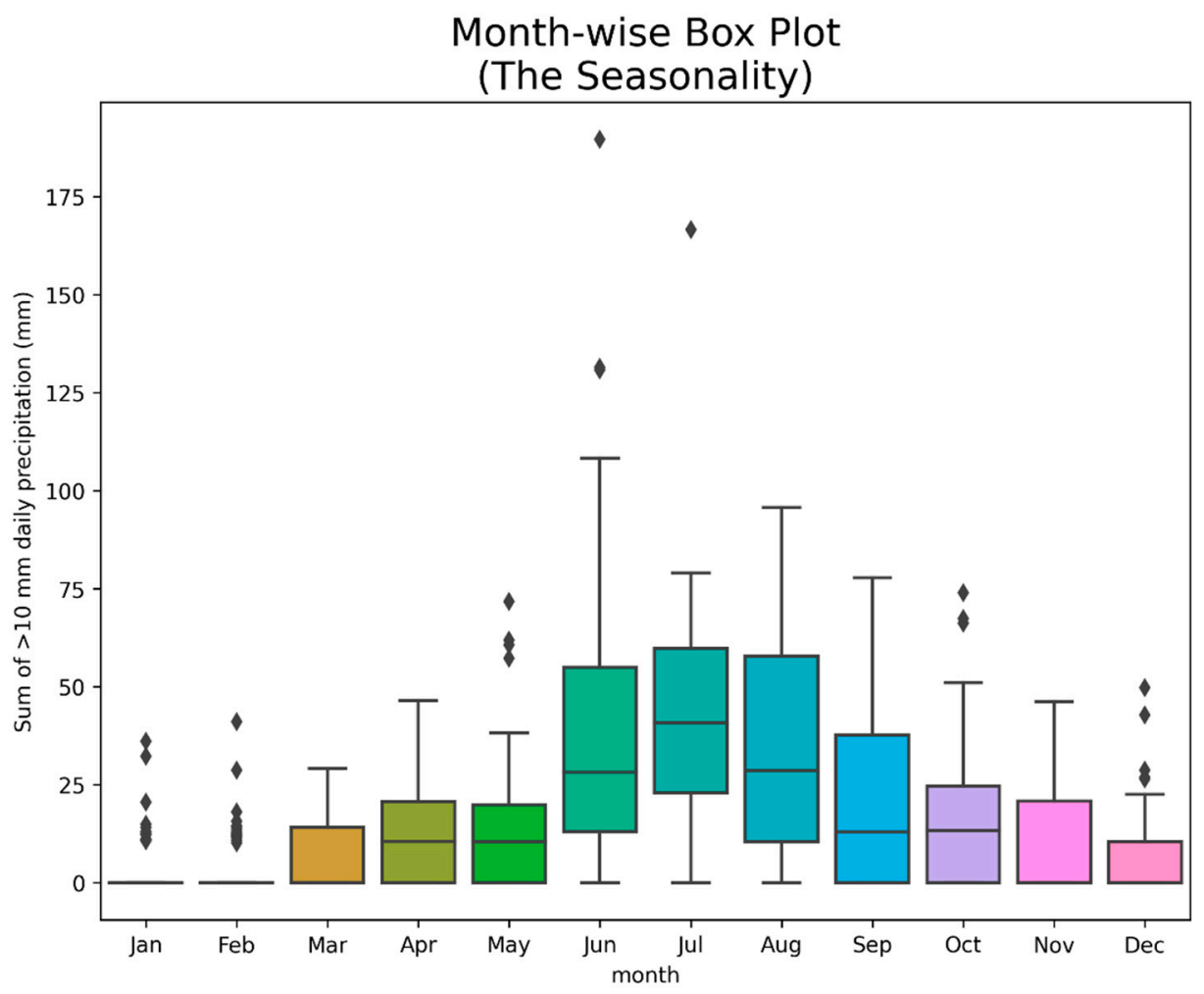

(A)

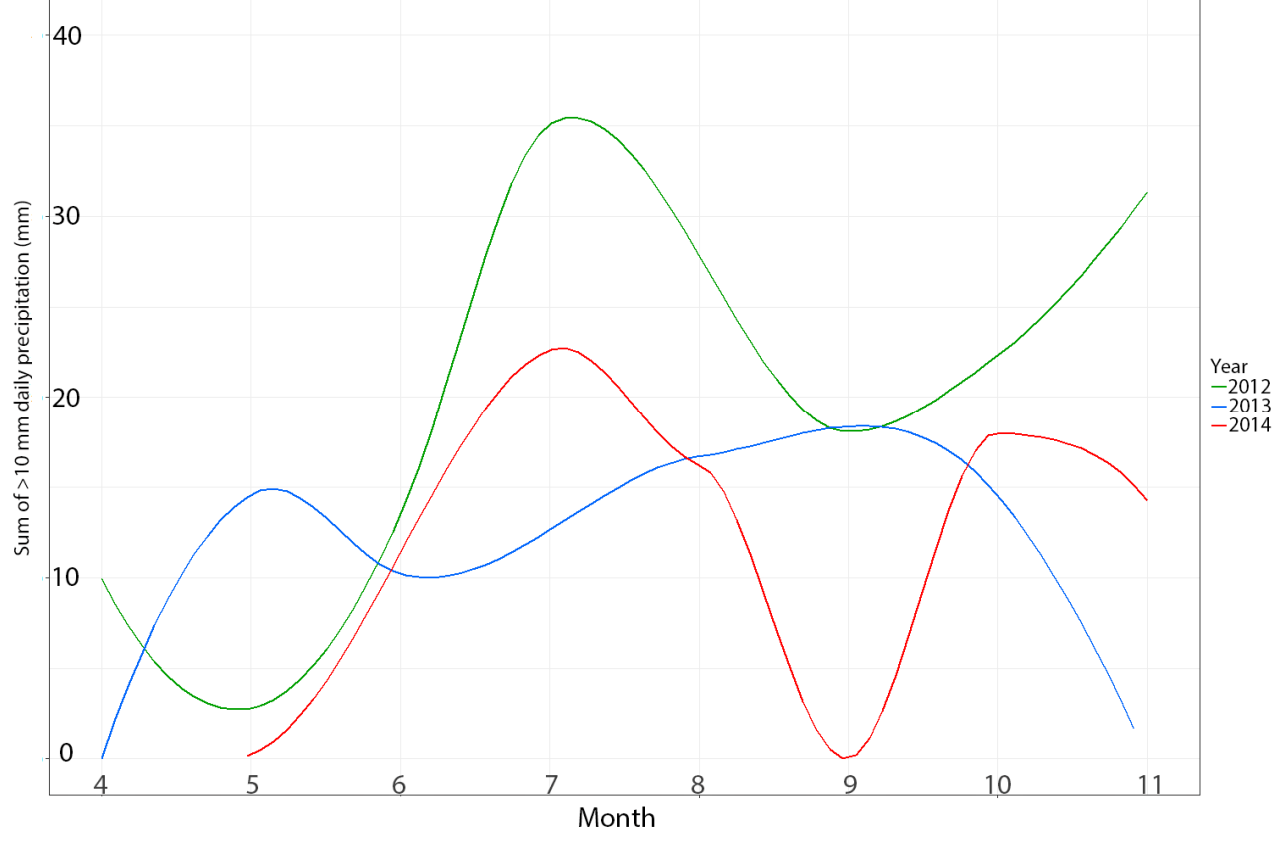

(B)

Figure 7. Seasonality (last decade) (A) and variability (B) of cumulative rainfall depth (mm.month ${ }^{-1}$ ) for days with more than $10 \mathrm{~mm}$ for the summer-fall periods of 2012-2014 at the study sites (according to Kazan Federal university meteorological station data).

The analysis of the dynamics of transverse profiles (Figure 8, Profile 1) showed that in the zone of block landslide development, the mass movement in the summer-autumn period is smaller than in the autumn-summer period. In the summer-autumn period of 2013, the landslide body did not change its position. Displacements of masses occur mainly during the snowmelt period. Therefore, in the autumn-summer period of 2013, the landslide mass moved downslope by $4 \mathrm{~m}$, and in 2014 by $3 \mathrm{~m}$. 

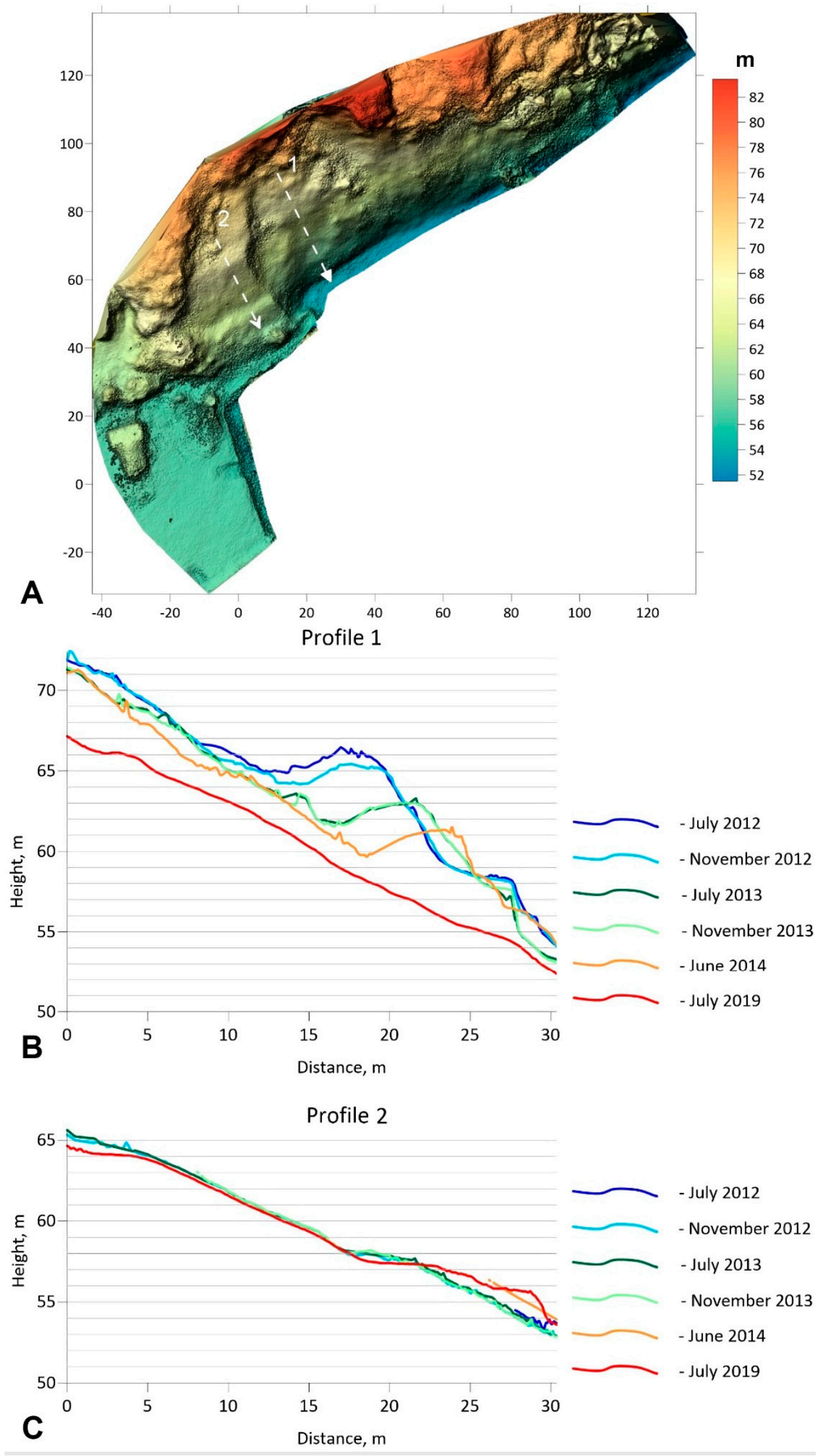

Figure 8. Site 1. 3D-model (2019) with location (A) of slope profiles 1 (B) and 2 (C) of the abrasionslope at site 1 . 
The graphs show that in November 2012, there was an accumulation of soil masses on the abrasion part of the bank slope. From November 2012 to July 2013, the accumulated material was intensively eroded. The reduction of the process intensity characterizes the summer-autumn period of 2013. Significant re-activation was observed in the period from November to June 2014. A significant difference is observed between the 2012-2014 and the 2019 slope profiles. The landslide body is not seen on the 2019 profile, which is almost straight. Over the last five years, the landslide body has been completely transformed; the profile of the slope has reached a dynamic equilibrium and has become linear. The average thickness of the transformed soil layer on the flattened sections was $1.5 \mathrm{~m}$ or $0.5 \mathrm{~m} \mathrm{yr}^{-1}$ during 2012-2014 and $2 \mathrm{~m} \mathrm{yr}^{-1}$ or $0.4 \mathrm{~m} \mathrm{yr}^{-1}$ during 2014-2019 (Figure 9).

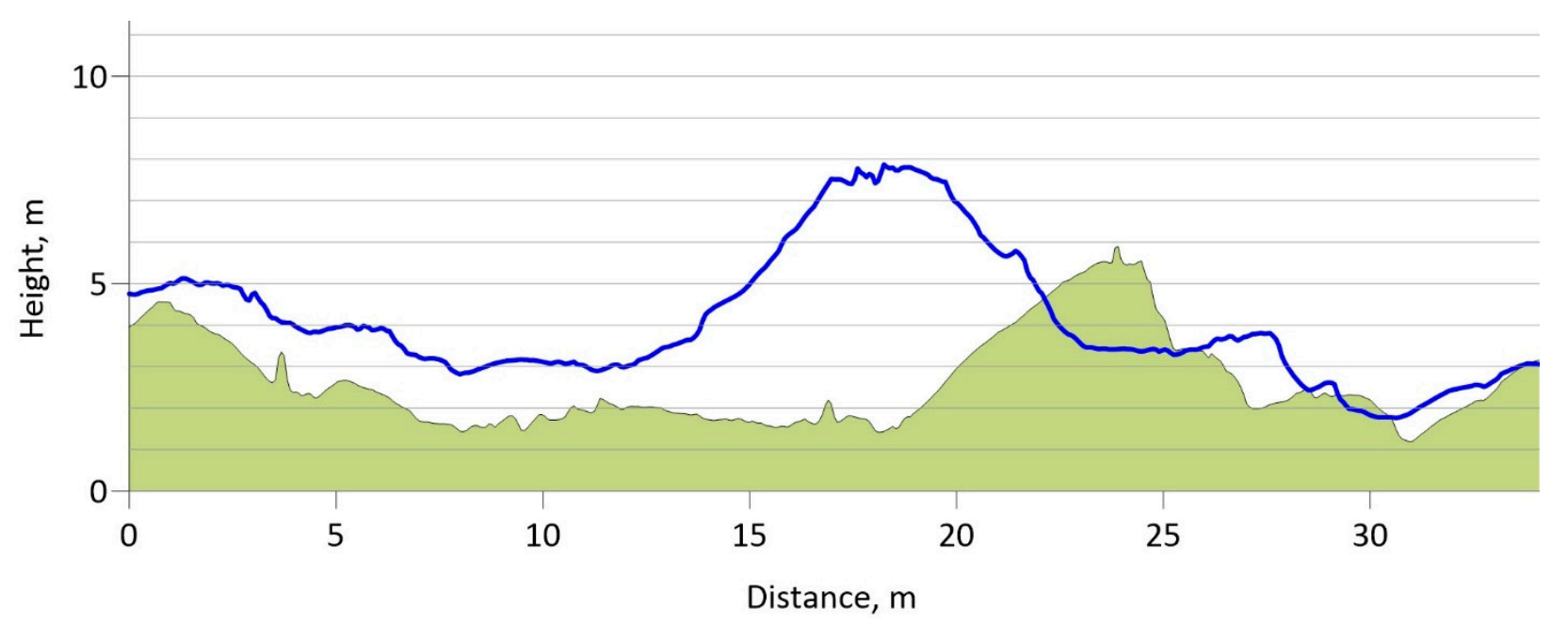

Figure 9. Site 1. Slope profile changes at site 1 in the period 2012-2019 (blue line) and 2014-2019 (green).

Based on the 2003-2006 survey, the authors recommended to install landslide-control measures, directed to protect the pier under construction. The essence of the measures consisted in the modelling of the landslide slope with subsequent flattening in 2007, installing engineering structures at the foot of the slope to protect it from wave action and to prevent the development of abrasion processes. The implemented measures turned out to be very effective. At present (2019), no landslide reactivation processes are observed on the treated part of the slope, which can be seen in Profile 2 (Figure 8).

\subsection{Observations at Site 2}

Landsliding was initiated at this site after the Kuibyshev reservoir filling in 1957, as shown in the archive images (Figure 10). On the 1958 image at the shore scarp foot small erosion forms of rill type can be observed. The 1985 image shows the slope transformation due to abrasion and landslide processes along the bank front, reaching the gully's left bank in the eastern part of the site. In 1987, the shoreline scarps began to take a circular shape, and later, the upper part of the slope was transformed by landslide processes. In the lower part, a landslide body is formed, which is gradually eroded due to abrasion by wave erosion.

The digitized scarp lines for different periods-(i.e., 1958-1975, 1975-1985, 19851987, 1987-1993, 1993-2002, 2002-2019) were analyzed to calculate the rate of landslide scarp retreat in DSAS. This is primarily due to the change in the slope's horizontal shape and transition into a cirque type of landslide. The plan shape of the scarp line was gradually changing from a line to an arc, which would introduce distortions when making measurements in the DSAS module. Therefore, it was decided to plot lines perpendicular to the baseline of the corresponding period separately. 


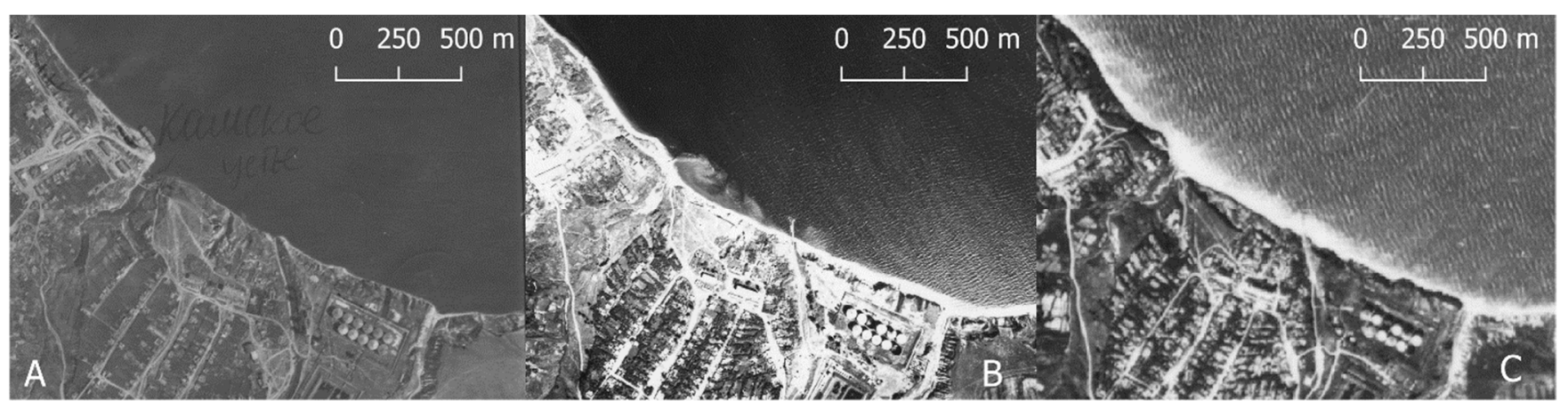

Figure 10. Site 2 depicted on the aerial images of 1958 (A), 1985 (B), and 1987 (C).

In general, the average rate of landslide slope retreat varies in the range of $1-2 \mathrm{~m} \mathrm{yr}^{-1}$ throughout the study period (Table 7). The period of 1985-1987 stands out as a landslide block moved downslope, and subsequently, the landslide changed to the cirque type and the scarp retreat rate decreased (Figure 11). The analysis of the landslide scarp retreat rate between 2002 and 2019 was conducted from the 2002 line because of the stabilization of the plan shape of the landslide scarp in subsequent years. This is partly due to the excavation works to improve the surrounding area, which leads to a reduction of the landslide scarp retreat rate to $0.84 \mathrm{~m} \mathrm{yr}^{-1}$ in 2019 which transferred the landslide to the moderately hazardous landslide category [79].

Table 7. Retreat rate of the landslide scarp at Site 2. See also Figure 11.

\begin{tabular}{ccc}
\hline & \multicolumn{2}{c}{ Retreat Rate $\left(\mathbf{m ~ y r}^{-\mathbf{1}}\right)$} \\
\cline { 2 - 3 } & Mean & Maximum \\
\hline 1975 & 1.89 & 2.12 \\
1985 & 1.45 & 1.92 \\
1987 & 8.73 & 11.29 \\
1993 & 3.50 & 6.38 \\
2002 & 1.28 & 2.67 \\
2003 & 1.35 & 2.57 \\
2005 & 1.28 & 2.43 \\
2010 & 1.34 & 2.49 \\
2019 & 1.12 & 2.04 \\
\end{tabular}

It should be noted that the study in 2002-2006 was carried out according to the state program, the aim of which was to analyze the landslide processes on both sites and to evaluate their hazard for nearby inhabited and uninhabited constructions. As a result of this study, several recommendations for landslide control measures were formulated. At Site 1 , following the recommendations made, shore protection constructions were installed, which made it possible to stabilize the landslide processes above it completely. Unfortunately, a shore protection dam was not installed along the slope's entire length (see Figure 2), which made it impossible to stabilize the entire landslide section. At Site 2, shore protection and improvement works were not organized until 2018-2019. When the camping base was constructed, approximately one-third of the landslide cirque was reduced, which also resulted in a reduction of the landsliding intensity (Figure 12). 


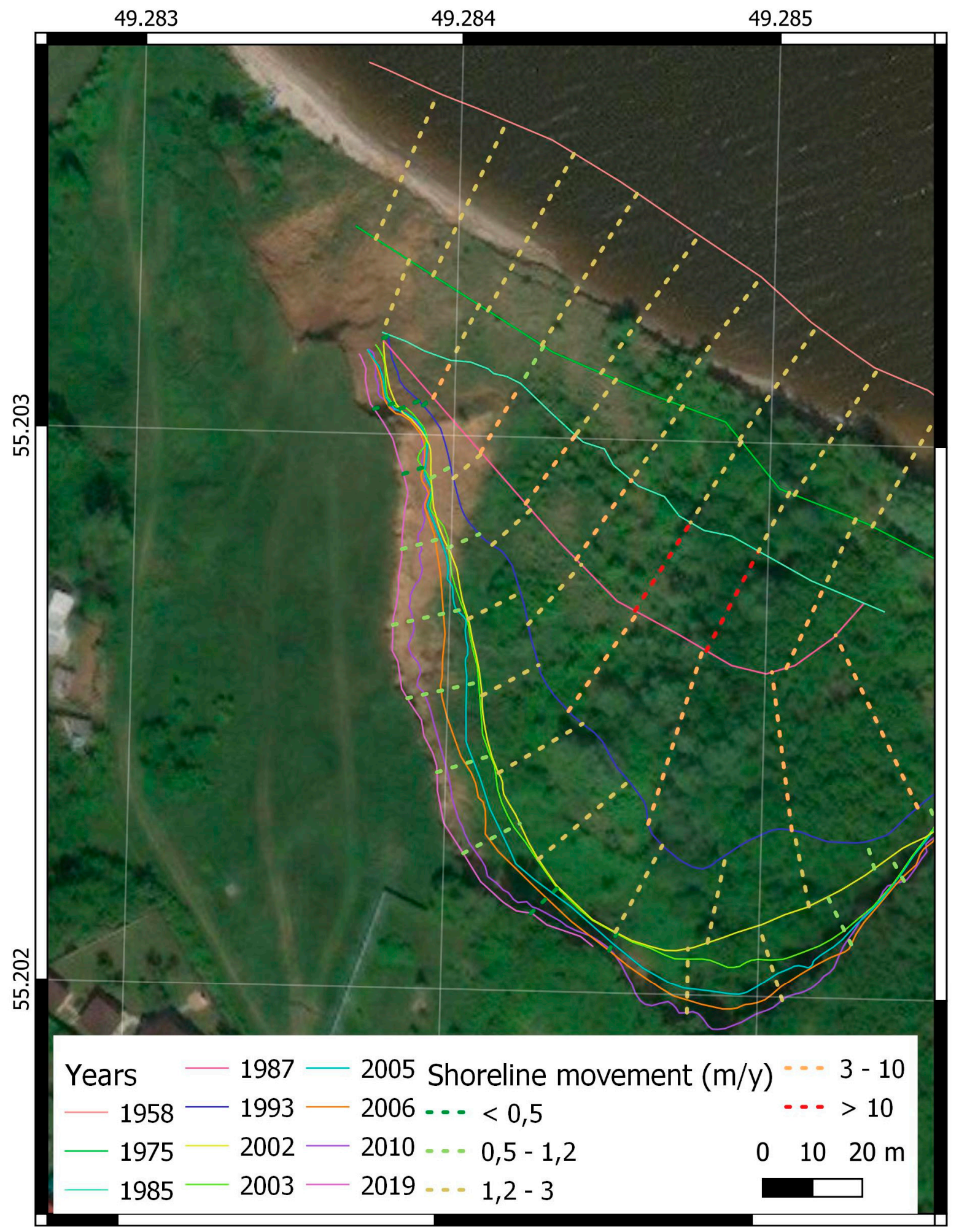

Figure 11. Site 2. Digital Globe image (2020). Evolution of landslide scarp edge and shoreline between 1958 and 2019. 


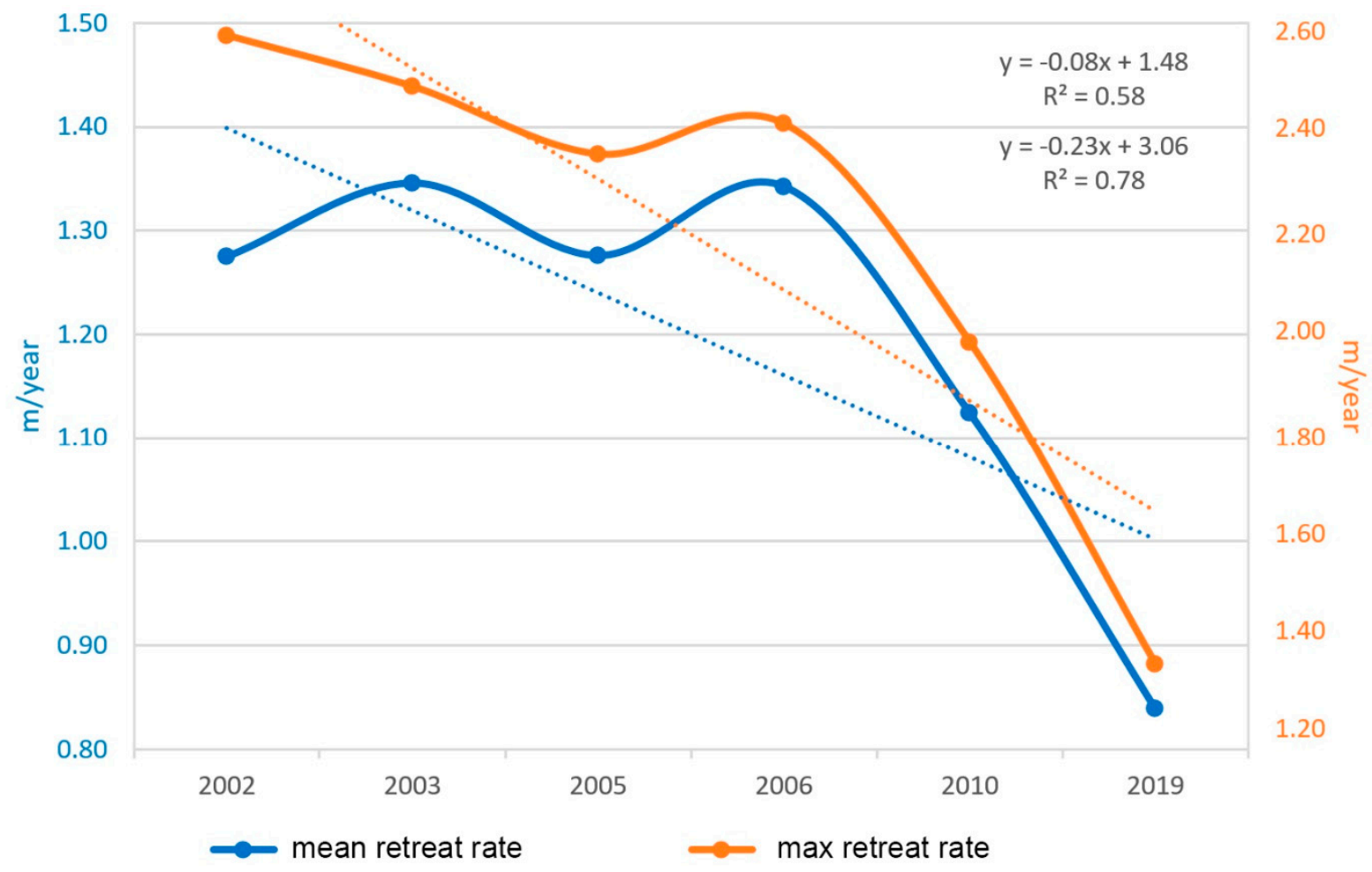

Figure 12. Evolution of the annual landslide scarp retreat rate at Site 2 since 2002, when high-precision instrumental fieldwork began.

\section{Discussion}

Using different remote sensing methods allows quantitative assessments of several exogenous processes at different scales and qualitative levels. Landslide processes may have different appearances, and their assessment requires different approaches [80,81]. Each tool solves the problem differently. Volumetric landslide changes evaluation is possible by calculating the difference of 3D models obtained by the outcomes of TLS and UAV. Assessment of planar displacements is possible by visual interpretation of remote sensing data and field monitoring of the boundaries of the study object using a total station survey. Satellite images, as well as simple aerial photos, do not permit the production of a volumetric picture. However, TLS does not permit the establishment of the exact position of the landslide body boundaries. Scanning total stations, permitting the solving of classical tachymetry tasks - that give the most exact position of object borders under research; and to make scans of landslide object for the subsequent three-dimensional reconstruction. TLS helps to estimate volumetric changes with millimeter accuracy. However, when estimating landslide structures located on the banks of reservoirs, access from all sides is difficult. It may give so-called shadows-areas with no information on three-dimensional data [82]. The UAV method does not have such a disadvantage; even though there are differences in the level of accuracy achieved, UAV data can significantly complement scanning results in areas with no data. Multi-temporal measurements alignment with only UAV is still tricky because of the UAVs navigation system inaccuracies.

Nevertheless, the error of georeferencing of multitemporal models is acceptable when assessing rapid landslides. Returning to the most optimal method, it can be noted that the use of UAV to assess planar and volumetric changes on slopes allows obtaining both a three-dimensional model and an ultrahigh-resolution orthophoto, with which the retreat of the slope scarp can be monitored. However, as noted earlier, the construction of accurate difference-time maps requires high-precision positioning of the aircraft itself, which is achieved using high-precision GNSS receivers that allow making corrections in real-time kinematics or post-processing. As the established practice of using such airborne 
systems has shown, the best results in comparing multi-temporal data can be achieved by simultaneous use of UAV image data with high-precision positioning, taking into account corrections from the base station and ground reference points [83].

The use of modern unmanned systems allows taking images with multispectral cameras that provide additional possibilities for analyzing the relationship between the spectral characteristics of rocks composing the landslide body and the intensity of the processes. However, comprehensive mathematical and statistical modeling is possible only with spatial data on fundamental factors of landslide formation - the steepness of slopes, soil texture and type of rocks, air temperature and precipitation data, especially for the winter period, groundwater depth data, and reservoir level fluctuations. However, for verification of modeling results, one needs data on currently developing landslides along the Kuibyshev reservoir banks, which is to be collected in the near future.

Active shoreline erosion currently occurs in almost all water reservoirs in Russia. In total, $36 \%$ of the shoreline of all water reservoirs in Russia is affected by these processes [84]. Shoreline erosion is most active within large reservoirs with a capacity of more than 10 million $\mathrm{m}^{3}$. For such water bodies in the European part of Russia about $40 \%$ of shores is transformed, in Siberia-36\%, in the Far East-35\%, while in small reservoirs, located in the same regions, only $13-15 \%$ of the total shoreline is affected by shoreline erosion [85].

Among the large water bodies of the European part of Russia, the most affected by bank destruction are the Kuibyshev (75\%), Volgograd (72\%), Saratov (70\%), and Gorky $(65 \%)$ reservoirs, located in forest-steppe and steppe zones. More than $50 \%$ of the banks are actively retreating at the Kama and Novosibirsk reservoirs. For other water bodies in Russia, shoreline degradation usually occurs on less than $40 \%$ of the shoreline.

Analysis of actual data on linear shoreline retreat rates showed that the maximum average annual retreat rates during the first 10 years of development of water reservoirs, i.e., during the first, active stage of the process development, amount to $10-20 \mathrm{~m} \mathrm{yr}^{-1}$. In some years, the indicated rates of bank erosion at the first stage can be significantly higher, up to $100 \mathrm{~m} \mathrm{yr}^{-1}$. Thus, in the eastern part of Kamskoye Ustie (Sites 1-2), a 70-90 m wide strip of coastline was destroyed by landslides during the first 30 years of the reservoir's existence. The average annual intensity of shoreline processes of the largest reservoirs of Russia at the second stage of development in the regime of steady-state or slowing-down deformations is, as a rule, significantly smaller and usually does not exceed 1-2.5 $\mathrm{m} \mathrm{yr}^{-1}$. The data obtained at the studied site are comparable with the data of previous studies [86], conducted mainly by standard surveying methods.

Nevertheless, at some sites, recent studies show much larger values of shoreline displacement, mainly in the areas with loams. This, for example, occurs near the village of Izmeri in Spassky District, Republic of Tatarstan (55.130452 N, 49.469740 E), where maximum retreat values reach $9 \mathrm{~m} \mathrm{yr}^{-1}$, with average values of $1-6 \mathrm{~m} \mathrm{yr}^{-1}$ [5].

Observations of coastal retreat and landslide processes have been made at the Kuibyshev reservoir [87-90], mainly focusing on the assessment of coastal retreat and land losses. Long-term observations of landslide processes are conducted mainly by state agencies by installing ground control points at random sections. Unfortunately, these data are not available for scientific studies and are not published.

The use of modern methodological approaches allows obtaining information on landslide processes independently, quickly, and efficiently. These allow estimating changes overall front of the landslide slope and dangerous areas, inaccessible to observations by traditional methods.

\section{Conclusions}

This paper documents quantitatively the dynamics of reservoir bank landslides and shoreline abrasion in active zones for the 1958-2019 period, based on the integrated use of modern instrumental methods. Assessment of the retreat rates of the landslide scarp is possible using both remote sensing from space and orthophoto maps obtained from UAVs and classical total station surveys. The use of historical archival aerial pho- 
tographs allows assessing the intensity of this land degradation process since the initiation of landslide processes. The monitoring of landslide processes using different measurement methods reveals that the rate of volumetric changes as a result of landslide processes at Site 1 has remained stable during the period of measurements (2012-2014) and is $-0.03-0.04 \mathrm{~m}^{3} \mathrm{~m}-{ }^{2} \mathrm{yr}^{-1}$, with the most significant contribution to the average annual value being caused by snowmelt runoff. The spatial dynamics of the landslide edge at Site 2 showed a steady decreasing trend of the retreat rate, beginning in 2002-2003, associated with partial overgrowth of the landslide accumulation zone and its relative stabilization. The average landslide scarp retreat rate for the entire observation period is $2.3 \mathrm{~m} \mathrm{yr}^{-1}$. In recent years' landslide control measures taken in this area have reduced the landslide scarp retreat rate by more than 2.5 times to $0.84 \mathrm{~m} \mathrm{yr}^{-1}$.

Author Contributions: Conceptualization, O.Y.; methodology, B.U. and A.G.; software, E.V.; validation, B.U. and E.V.; formal analysis, A.G.; investigation, B.U.; resources, O.Y., B.U., A.G., J.P., E.V., F.L. and I.C.N.; writing—original draft preparation, B.U. and A.G.; writing—review and editing, F.L., J.P. and I.C.N.; visualization, A.G., F.L. and I.C.N.; supervision, J.P.; project administration, O.Y. All authors have read and agreed to the published version of the manuscript.

Funding: The study was carried out with the support of the Russian Science Foundation (project №19-17-00064-working methodology, preparation, and analysis of data; project №20-67-46017mathematical and statistical data processing); Kazan Federal University Strategic Academic Leadership Program (aerial photo archives).

Data Availability Statement: The data presented in this study are available on request from the first author.

Conflicts of Interest: The authors declare no conflict of interest.

\section{References}

1. Yermolaev, O.; Usmanov, B. The basin approach to the anthropogenic impact assessment in oil-producing region. In Proceedings of the International Multidisciplinary Scientific GeoConference Surveying Geology and Mining Ecology Management, SGEM, Albena, Bulgaria, 17-26 June 2014; Volume 2, pp. 681-688.

2. Yermolaev, O.; Usmanov, B.; Muharamova, S.S. The basin approach and mapping to the anthropogenic impact assessment on the east of the russian plain. Int. J. Appl. Eng. Res. 2015, 10, 41178-41184.

3. Nicu, I.; Usmanov, B.; Gainullin, I.; Galimova, M. Shoreline dynamics and evaluation of cultural heritage sites on the shores of large reservoirs: Kuibyshev reservoir, russian federation. Water 2019, 11, 591. [CrossRef]

4. Yermolaev, O.; Mukharamova, S.; Vedeneeva, E. River runoff modeling in the european territory of Russia. Catena 2021, 203, 105327. [CrossRef]

5. Usmanov, B.; Nicu, I.C.; Gainullin, I.; Khomyakov, P. Monitoring and assessing the destruction of archaeological sites from kuibyshev reservoir coastline, Tatarstan Republic, Russian Federation. A Case Study. J. Coast. Conserv. 2018, 22, 417-429. [CrossRef]

6. Gafurov, A.M.; Yermolayev, O.P. Automatic gully detection: Neural networks and computer vision. Remote Sens. 2020, 12, 1743. [CrossRef]

7. Degraff, J.; Olson, E. Landslide monitoring techniques for wildland management. J. Soil Water Conserv. 1980, 35, $241-242$.

8. Scaioni, M. Modern Technologies for Landslide Monitoring and Prediction; Springer: Berlin/Heidelberg, Germany, 2015; ISBN 978-3-662-45930-0.

9. Savvaidis, P. Existing landslide monitoring systems and techniques. Stars Earth Cult. 2003, 242-258.

10. Tsai, Z.-X.; You, G.J.-Y.; Lee, H.-Y.; Chiu, Y.-J. Use of a total station to monitor post-failure sediment yields in landslide sites of the Shihmen Reservoir Watershed, Taiwan. Geomorphology 2012, 139-140, 438-451. [CrossRef]

11. Pradhan, B. Laser Scanning Applications in Landslide Assessment; Springer International Publishing: Cham, Switzerland, 2017; ISBN 978-3-319-55341-2.

12. Gafurov, A.M.; Rysin, I.I.; Golosov, V.N.; Grigoryev, I.I.; Sharifullin, A.G. Estimation of the recent rate of gully head retreat on the southern megaslope of the East European Plain using a set of instrumental methods. Vestn. Mosk. Univ. Seriya 5 Geogr. 2018, 61-71.

13. Gupta, S.K.; Shukla, D.P. Application of drone for landslide mapping, dimension estimation and its 3D reconstruction. J. Indian Soc. Remote Sens. 2018, 46, 903-914. [CrossRef]

14. Mertens, K.; Jacobs, L.; Maes, J.; Poesen, J.; Kervyn, M.; Vranken, L. Disaster risk reduction among households exposed to landslide hazard: A crucial role for self-efficacy? Land Use Policy 2018, 75, 77-91. [CrossRef] 
15. Casagli, N.; Frodella, W.; Morelli, S.; Tofani, V.; Ciampalini, A.; Intrieri, E.; Raspini, F.; Rossi, G.; Tanteri, L.; Lu, P. Spaceborne, UAV and ground-based remote sensing techniques for landslide mapping, monitoring and early warning. Geoenvironmental Disasters 2017, 4, 9. [CrossRef]

16. Yang, I.T.; Park, J.K.; Kim, D.M. Monitoring the symptoms of landslide using the non-prism total station. KSCE J. Civ. Eng. 2007, 11, 293-301. [CrossRef]

17. Bertacchini, E.; Capitani, A.; Capra, A.; Corsini, A.; Dubbini, M. Integrated surveying system for landslide monitoring, Valoria Landslide (Appennines of Modena, Italy). In Proceedings of the FIG Working Week, FIG Federation Internationale des Geometres, Eilat, Israel, 3-8 May 2009; Volume TS3F-n. 3343, p. 11.

18. Barbarella, M.; Fiani, M. Monitoring of large landslides by terrestrial laser scanning techniques: Field data collection and processing. Eur. J. Remote Sens. 2013, 46, 126-151. [CrossRef]

19. Chigira, M.; Duan, F.; Yagi, H.; Furuya, T. Using an Airborne laser scanner for the identification of shallow landslides and susceptibility assessment in an area of ignimbrite overlain by permeable pyroclastics. Landslides 2004, 1, 203-209. [CrossRef]

20. Monserrat, O.; Crosetto, M. Deformation measurement using terrestrial laser scanning data and least squares $3 \mathrm{~d}$ surface matching. ISPRS J. Photogramm. Remote Sens. 2008, 63, 142-154. [CrossRef]

21. Dunning, S.A.; Massey, C.I.; Rosser, N.J. Structural and geomorphological features of landslides in the bhutan himalaya derived from terrestrial laser scanning. Geomorphology 2009, 103, 17-29. [CrossRef]

22. Viero, A.; Teza, G.; Massironi, M.; Jaboyedoff, M.; Galgaro, A. Laser scanning-based recognition of rotational movements on a deep seated gravitational instability: The Cinque Torri case (North-Eastern Italian Alps). Geomorphology 2010, 122, 191-204. [CrossRef]

23. Vaaja, M.; Hyyppä, J.; Kukko, A.; Kaartinen, H.; Hyyppä, H.; Alho, P. Mapping topography changes and elevation accuracies using a mobile laser scanner. Remote Sens. 2011, 3, 587-600. [CrossRef]

24. Altuntas, C.; Karabork, H.; Tusat, E. Georeferencing of ground-based LIDAR data using continuously operating reference stations. Opt. Eng. 2014, 53, 1-8. [CrossRef]

25. Oppikofer, T.; Jaboyedoff, M.; Blikra, L.; Derron, M.-H.; Metzger, R. Characterization and monitoring of the Aknes rockslide using terrestrial laser scanning. Nat. Hazards Earth Syst. Sci. 2009, 9, 1003-1019. [CrossRef]

26. Usmanov, B.; Yermolaev, O.; Gafurov, A. Estimates of slope erosion intensity utilizing terrestrial laser scanning. Proc. Int. Assoc. Hydrol. Sci. 2015, 367, 59-65. [CrossRef]

27. Barbarella, M.; Fiani, M.; Lugli, A. Landslide monitoring using multitemporal terrestrial laser scanning for ground displacement analysis. Geomat. Nat. Hazards Risk 2015, 6, 398-418. [CrossRef]

28. Gafurov, A.M.; Yermolaev, O.P.; Usmanov, B.M. Assessment of the intensity of slope erosion using terrestrial laser scanning. Int. J. Pharm. Technol. 2016, 8, 14822-14832.

29. Gruen, A.; Akca, D. Least squares 3D surface and curve matching. ISPRS J. Photogramm. Remote Sens. 2005, 59, 151-174. [CrossRef]

30. Pesci, A.; Teza, G.; Casula, G.; Loddo, F.; De Martino, P.; Dolce, M.; Obrizzo, F.; Pingue, F. Multitemporal laser scanner-based observation of the Mt. vesuvius crater: Characterization of overall geometry and recognition of landslide events. ISPRS J. Photogramm. Remote Sens. 2011, 66, 327-336. [CrossRef]

31. Kociuba, W.; Kubisz, W.; Zagórski, P. Use of terrestrial laser scanning (TLS) for monitoring and modelling of geomorphic processes and phenomena at a small and medium spatial scale in polar environment (Scott River-Spitsbergen). Geomorphology 2014, 212, 84-96. [CrossRef]

32. Michoud, C.; Carrea, D.; Costa, S.; Derron, M.-H.; Jaboyedoff, M.; Delacourt, C.; Maquaire, O.; Letortu, P.; Davidson, R. Landslide Detection and monitoring capability of boat-based mobile laser scanning along Dieppe Coastal Cliffs, Normandy. Landslides 2015, 12, 403-418. [CrossRef]

33. Palenzuela, J.A.; Jiménez-Perálvarez, J.D.; El Hamdouni, R.; Alameda-Hernández, P.; Chacón, J.; Irigaray, C. Integration of LiDAR data for the assessment of activity in diachronic landslides: A case study in the Betic Cordillera (Spain). Landslides 2016, 13, 629-642. [CrossRef]

34. Franz, M.; Carrea, D.; Abellán, A.; Derron, M.-H.; Jaboyedoff, M. Use of targets to track 3D displacements in highly vegetated areas affected by landslides. Landslides 2016, 13, 821-831. [CrossRef]

35. Yermolaev, O.P.; Gafurov, A.M.; Usmanov, B.M. Evaluation of erosion intensity and dynamics using terrestrial laser scanning. Eurasian Soil Sci. 2018, 51, 814-826. [CrossRef]

36. Spreafico, M.C.; Perotti, L.; Cervi, F.; Bacenetti, M.; Bitelli, G.; Girelli, V.A.; Mandanici, E.; Tini, M.A.; Borgatti, L. Terrestrial remote sensing techniques to complement conventional geomechanical surveys for the assessment of landslide hazard: The San Leo case study (Italy). Eur. J. Remote Sens. 2015, 48, 639-660. [CrossRef]

37. Wang, X.; Pedrycz, W.; Niu, R. Spatio-temporal analysis of quaternary deposit landslides in the Three Gorges. Nat. Hazards 2015, 75, 2793-2813. [CrossRef]

38. Zhang, Y.; Zhu, S.; Tan, J.; Li, L.; Yin, X. The influence of water level fluctuation on the stability of landslide in the Three Gorges reservoir. Arab. J. Geosci. 2020, 13, 845. [CrossRef]

39. Guo, Z.; Chen, L.; Yin, K.; Shrestha, D.P.; Zhang, L. Quantitative risk assessment of slow-moving landslides from the viewpoint of decision-making: A case study of the Three Gorges reservoir in China. Eng. Geol. 2020, 273, 105667. [CrossRef]

40. Starodubtsev, V.M. Impact of Bugun' water reservoir on coast for 50 years. Arid Ecosyst. 2012, 2, 132-138. [CrossRef] 
41. Babicheva, V.A.; Rzetala, M.A. The main types of banks of Angara water reservoirs: Overview of the problem. Int. Multidiscip. Sci. GeoConference SGEM 2013, 1, 195-202. [CrossRef]

42. Kalinin, V.G.; Nazarov, N.N.; Pyankov, S.V.; Simirenov, S.A.; Tynyatkin, D.G. activity of the landslide on the bank of the Kamskoe Storage reservoir according to stationary measurements and GIS-technology application. Geomorphol. RAS 2015, 55-62. [CrossRef]

43. Bondur, V.G.; Zakharova, L.N.; Zakharov, A.I.; Chimitdorzhiev, T.N.; Dmitriev, A.V.; Dagurov, P.N. Monitoring of landslide processes by means of L-band radar interferometric observations: Bureya River bank caving case. Issled. Zemli Iz Kosmosa 2019, 3-14. [CrossRef]

44. Mazaeva, O.; Babicheva, V.; Kozyreva, E. Geomorphological process development under the impact of man-made reservoir operation, a case study: Bratsk Reservoir, Baikal-Angara hydroengineering system, Russia. Bull. Eng. Geol. Environ. 2019, 78, 4659-4672. [CrossRef]

45. Nikonorova, I.V.; Petrov, N.F.; Gumenyuk, A.E.; Ilyin, V.N. Sustainable use of natural resources in a hazardous landslide slopes of Cheboksary reservoir (River Volga). In Proceedings of the International Conference on Extraction, Transport, Storage and Processing of Hydrocarbons and Minerals, Tyumen, Russia, 19-20 August 2019; Volume 663, p. 012043. [CrossRef]

46. Marzolff, I.; Poesen, J. The potential of 3D gully monitoring with GIS using high-resolution aerial photography and a digital photogrammetry system. Geomorphology 2009, 111, 48-60. [CrossRef]

47. Marzolff, I.; Ries, J.B.; Poesen, J. Short-term versus medium-term monitoring for detecting gully-erosion variability in a mediterranean environment. Earth Surf. Process. Landf. 2011, 36, 1604-1623. [CrossRef]

48. Gafurov, A.M. Possible use of unmanned aerial vehicle for soil erosion assessment. Uchenye Zap. Kazan. Univ.-Seriya Estestv. Nauki 2017, 159, 654-667.

49. Eker, R.; Aydın, A.; Hübl, J. Unmanned aerial vehicle (UAV)-based monitoring of a landslide: Gallenzerkogel landslide (YbbsLower Austria) case study. Environ. Monit. Assess. 2018, 190, 28. [CrossRef]

50. Agisoft PhotoScan User Manual—Professional Edition, version 1.4; Agisoft LLC: St. Petersburg, Russia, 2018.

51. Bradski, G.; Kaehler, A. Learning OpenCV: Computer Vision with the OpenCV Library, Software that Sees, 1st ed.; O'Reilly: Sebastopol, CA, USA, 2011; ISBN 978-0-596-51613-0.

52. D'Oleire-Oltmanns, S.; Marzolff, I.; Peter, K.D.; Ries, J.B.; Hssaïne, A.A. Monitoring soil erosion in the Souss Basin, Morocco, with a multiscale object-based remote sensing approach using UAV and satellite data. In Proceedings of the 1st World Sustainability Forum, Basel, Switzerland, 1-15 November 2011; pp. 1-13.

53. D'Oleire-Oltmanns, S.; Marzolff, I.; Peter, K.; Ries, J. Unmanned aerial vehicle (UAV) for monitoring soil erosion in Morocco. Remote Sens. 2012, 4, 3390-3416. [CrossRef]

54. Fritz, A.; Kattenborn, T.; Koch, B. UAV-based photogrammetric point clouds-Tree stem mapping in open stands in comparison to terrestrial laser scanner point clouds. In Proceedings of the International Archives of the Photogrammetry, Remote Sensing and Spatial Information Sciences, Rostock, Germany, 4-6 September 2013; Volume V XL-1/W2, pp. 141-146. [CrossRef]

55. Vasuki, Y.; Holden, E.-J.; Kovesi, P.; Micklethwaite, S. Semi-automatic mapping of geological structures using UAV-based photogrammetric data: An image analysis approach. Comput. Geosci. 2014, 69, 22-32. [CrossRef]

56. Savin, I.; Prudnikova, E.; Chendev, Y.; Bek, A.; Kucher, D.; Dokukin, P. Detection of changes in arable chernozemic soil health based on landsat TM archive data. Remote Sens. 2021, 13, 2411. [CrossRef]

57. Terekhin, E.A. Spectral response of abandoned arable lands in various climate and environmental conditions of European Russia. Sovrem. Probl. Distantsionnogo Zondirovaniya Zemli Kosmosa 2021, 18, 169-181. [CrossRef]

58. Gruszczyński, W.; Matwij, W.; Ćwiąkała, P. Comparison of low-altitude uav photogrammetry with terrestrial laser scanning as data-source methods for terrain covered in low vegetation. ISPRS J. Photogramm. Remote Sens. 2017, 126, 168-179. [CrossRef]

59. Gafurov, A.M. Small catchments DEM creation using unmanned aerial vehicles. In Proceedings of the 3rd International Conference Environment and Sustainable Development of Territories: Ecological Challenges of the 21st Century, Kazan, Russia, 27-29 September 2017; Volume 107, p. 012005. [CrossRef]

60. Lucieer, A.; Turner, D.; King, D.H.; Robinson, S.A. Using an unmanned aerial vehicle (UAV) to capture micro-topography of Antarctic Moss Beds. Int. J. Appl. Earth Obs. Geoinformation 2014, 27, 53-62. [CrossRef]

61. Richter, N.; Favalli, M.; de Zeeuw-van Dalfsen, E.; Fornaciai, A.; da Silva Fernandes, R.M.; Pérez, N.M.; Levy, J.; Victória, S.S.; Walter, T.R. Lava flow hazard at Fogo Volcano, Cabo Verde, before and after the 2014-2015 eruption. Nat. Hazards Earth Syst. Sci. 2016, 16, 1925-1951. [CrossRef]

62. Müller, D.; Walter, T.R.; Schöpa, A.; Witt, T.; Steinke, B.; Gudmundsson, M.T.; Dürig, T. High-resolution digital elevation modeling from TLS and UAV campaign reveals structural complexity at the 2014/2015 Holuhraun Eruption Site, Iceland. Front. Earth Sci. 2017, 5, 59. [CrossRef]

63. Cawood, A.J.; Bond, C.E.; Howell, J.A.; Butler, R.W.H.; Totake, Y. LiDAR, UAV or Compass-clinometer? Accuracy, coverage and the effects on structural models. J. Struct. Geol. 2017, 98, 67-82. [CrossRef]

64. James, M.R.; Robson, S. Mitigating systematic error in topographic models derived from UAV and ground-based image networks. Earth Surf. Process. Landf. 2014, 39, 1413-1420. [CrossRef]

65. Udin, W.S.; Ahmad, A. Assessment of photogrammetric mapping accuracy based on variation flying altitude using unmanned aerial vehicle. In Proceedings of the 8th International Symposium of the Digital Earth, Kuching, Malaysia, 26-29 August 2014; Volume 18, pp. 1-7. [CrossRef] 
66. Uysal, M.; Toprak, A.S.; Polat, N. DEM generation with UAV photogrammetry and accuracy analysis in Sahitler Hill. Measurement 2015, 73, 539-543. [CrossRef]

67. Gindraux, S.; Boesch, R.; Farinotti, D. Accuracy assessment of digital surface models from unmanned aerial vehicles' imagery on glaciers. Remote Sens. 2017, 9, 186. [CrossRef]

68. Benassi, F.; Dall'Asta, E.; Diotri, F.; Forlani, G.; Morra di Cella, U.; Roncella, R.; Santise, M. Testing accuracy and repeatability of UAV blocks oriented with GNSS-supported aerial triangulation. Remote Sens. 2017, 9, 172. [CrossRef]

69. Turner, D.; Lucieer, A.; Watson, C. An automated technique for generating georectified mosaics from ultra-high resolution unmanned aerial vehicle (UAV) imagery, based on structure from motion (SfM) point clouds. Remote Sens. 2012, 4, 1392-1410. [CrossRef]

70. Gafurov, A. The methodological aspects of constructing a high-resolution DEM of large territories using low-cost UAVs on the example of the sarycum aeolian complex, Dagestan, Russia. Drones 2021, 5, 7. [CrossRef]

71. Agüera-Vega, F.; Carvajal-Ramírez, F.; Martínez-Carricondo, P.; Sánchez-Hermosilla López, J.; Javier Mesas-Carrascosa, F.; García-Ferrer, A.; Juan Pérez-Porras, F. Reconstruction of extreme topography from UAV structure from motion photogrammetry. Measurement 2018, 121, 127-138. [CrossRef]

72. Yermolaev, O.P. Geoinformation Mapping of soil erosion in the Middle Volga region. Eurasian Soil Sci. 2017, 50, 118-131. [CrossRef]

73. Cruden, D.; Varnes, D. Landslide Types and Processes; Special Report; National Academy Press: Washington, DC, USA, 1996; Dalam: Turner, AK Landslides Investigation and Mitigation.

74. Peppa, M.V.; Mills, J.P.; Moore, P.; Miller, P.E.; Chambers, J.E. Accuracy assessment of a UAV-based landslide monitoring system. ISPRS-Int. Arch. Photogramm. Remote Sens. Spat. Inf. Sci. 2016, XLI-B5, 895-902. [CrossRef]

75. Zang, Y.; Yang, B.; Li, J.; Guan, H. An accurate TLS and UAV image point clouds registration method for deformation detection of chaotic hillside areas. Remote Sens. 2019, 11, 647. [CrossRef]

76. Himmelstoss, E.A.; Henderson, R.; Kratzmann, M.; Farris, A. Digital Shoreline Analysis System; Version 5; Reston, VA, USA, 2018.

77. Oyedotun, T.D.T. Shoreline geometry: DSAS as a tool for historical trend analysis. Geomorphol. Tech. Online Ed. 2014, 3, 1-12.

78. Nicu, I.C. Is digital shoreline analysis system "Fit" for gully erosion assessment? CATENA 2021, 203, 105307. [CrossRef]

79. Ragozin, A.L.; Burova, V.N. A method for approximate forecast of reservoir bank destruction. J. Gidrotekhnicheskoe Stroit. 1993, 10, 20-26.

80. Broeckx, J.; Maertens, M.; Isabirye, M.; Vanmaercke, M.; Namazzi, B.; Deckers, J.; Tamale, J.; Jacobs, L.; Thiery, W.; Kervyn, M.; et al. Landslide susceptibility and mobilization rates in the Mount Elgon Region, Uganda. Landslides 2019, 16, 571-584. [CrossRef]

81. Broeckx, J.; Rossi, M.; Lijnen, K.; Campforts, B.; Poesen, J.; Vanmaercke, M. Landslide mobilization rates: A global analysis and model. Earth-Sci. Rev. 2020, 201, 102972. [CrossRef]

82. Devoto, S.; Macovaz, V.; Mantovani, M.; Soldati, M.; Furlani, S. Advantages of using UAV digital photogrammetry in the study of slow-moving coastal landslides. Remote Sens. 2020, 12, 3566. [CrossRef]

83. Gili, J.A.; Corominas, J.; Rius, J. Using global positioning system techniques in landslide monitoring. Eng. Geol. 2000, 55, 167-192. [CrossRef]

84. Burova, V.N. Abrasion risk assessment on the coasts of seas and water reservoirs. Geod. List 2020, 74, 185-198.

85. Ovchinnikov, G.I.; Maksimishina, Y.S. The importance of geological-geomorphological factors in the development of abrasion processes on the coasts of the Bratsk Reservoir, in the SE part of Russia. Landf. Anal. 2002, 3.

86. Middle Volga. Geomorphological Guidebook; Dedkov, A.P., Ed.; in Russian; Publishing House of Kazan University: Kazan, Russia, 1991.

87. Kotlyakov, A.V.; Shumakova, E.M.; Artem'ev, S.A. Dynamics of the coastal zone of the Kuibyshev and Saratov reservoirs in the Tolyatti Area and Its correlation with the operation regime of the Zhigulevskaya HPP. Water Resour. 2007, 34, 657-662. [CrossRef]

88. Gaynullin, I.; Sitdikov, A.; Usmanov, B. Destructive abrasion processes study in archaeological sites placement (Kuibyshev and Nizhnekamsk Reservoirs, Russia). In Proceedings of the International Multidisciplinary Scientific Conference on Social Sciences \& Arts SGEM, Albena, Bulgaria, 2-7 September 2014; pp. 339-346.

89. Gaynullin, I.I.; Sitdikov, A.G.; Usmanov, B.M. Abrasion processes of Kuibyshev Reservoir as a factor of destruction of archaeological site Ostolopovo (Tatarstan, Russia). Adv. Environ. Biol. 2014, 8, 1027-1030.

90. Bespalova, K.V.; Selezneva, A.V.; Seleznev, V.A. Influence of the water discharge of the Kuibyshev reservoir on the dynamics of the ecosystem of the Seredysh and Bakhilovsky Islands, the Volga River, Russia. In Proceedings of the 4th Conference on Actual problems of specially protected natural areas, Togljatti, Russia, 17-18 September 2020; Volume 607, p. 012017. [CrossRef] 